\title{
Abstracts from the Conjoint Annual Meeting of L'Association des pneumologues de la province de Québec, la Société de thoracologie du Québec and le Réseau en santé respiratoire du FRSQ
}

\begin{abstract}
1
ROLE OF POTASSIUM CHANNELS AND EPIDERMAL GROWTH FACTOR IN ALVEOLAR EPITHELIAL CELL REPAIR PROCESSES

NTN Trinh ${ }^{1}$, A Privé1, L Kheir ${ }^{1}$, MG Amraei ${ }^{2}$, J Noël ${ }^{2}$, E Brochiero ${ }^{1}$ ${ }^{1}$ Département de Médecine; ${ }^{2}$ Physiologie de l'Université de Montréal, Montréal, Québec

Several respiratory diseases are associated with extensive damage of lung epithelia. The regulatory mechanisms involved in alveolar epithelia regeneration after injury are not clearly defined. Growth factors released by epithelial cells or fibroblasts from damaged lungs are important regulators of alveolar repair by stimulating cell motility, proliferation and differentiation. In addition, $\mathrm{K}+$ channels have been shown to regulate cell proliferation and migration and to be coupled with growth factor signalling in several tissues. We decided to explore the hypothesis that $\mathrm{K}+$ could play a prominent role in lung epithelia repair. This hypothesis has never been investigated before. We employed a model of mechanical wounding of alveolar epithelia to study the response to injury. Wound-healing was inhibited by half upon EGF titration with an EGF antibody, whereas the addition of exogenous EGF slightly stimulated the wound-healing of alveolar monolayers. EGF addition also stimulated, by up to 5 times, alveolar cell migration. The impact of $\mathrm{K}+$ channel modulators was examined in basal and EGF-stimulated conditions. Wound-healing was stimulated by pinacidil, a $\mathrm{K}_{\text {ATP }}$ activator, which also increased alveolar cell migration, by 2-fold, in basal conditions and potentiated the stimulatory effect of EGF. In the presence of $K_{A T P}$ or KvLQT1 inhibitors (glibenclamide, clofilium), wound-healing and cell migration were reduced by 45 to $75 \%$. Finally, acute and long-term treatment with EGF stimulated $\mathrm{K}_{\text {ATP }}$ and KvLQT1 channel activity and expression. In summary, stimulation of $\mathrm{K}+$ channels through autocrine activation of EGF receptors plays a crucial role in lung epithelia repair processes.
\end{abstract}

\section{2}

\section{STUDY OF THE RELATION BETWEEN HYPOXIA AND} MUSCLE PROTEOLYSIS

M Caron, M Paré, F Maltais, R Debigaré

Department of Respirology, Laval Hospital, Quebec

BACKGROUND: Chronic obstructive pulmonary disease (COPD) is a progressive and irreversible disease regularly accompanied with peripheral muscle atrophy, which has tragic clinical consequences. Factors contributing to muscle atrophy in these patients are still unknown. Intermittent to chronic hypoxemia follow the progression of COPD. Several evidences suggest a link between muscle proteolysis and hypoxia.

PURPOSE: We propose that hypoxia contributes to muscle atrophy by: 1) increasing ubiquitin-proteasome (UP) sub-units expression; 2) decreasing the activity of the IGF/PI3K/Akt pathway, a major pathway involved in contractile protein synthesis.

METHODS: $\mathrm{L} 6$ myotubes were exposed to normoxic $\left(21 \% \mathrm{O}_{2}\right)$ or hypoxic $\left(1 \% \mathrm{O}_{2}\right)$ atmosphere. After 24 hours of hypoxic exposure, we found an accumulation of a $14 \mathrm{kDa}$ actin fragment, confirming the presence of proteolysis in this condition. Furthermore, we noted an increase in the expression of Atrogin-1, a muscle-specific component of the UP. These changes were attenuated by an insulin treatment, suggesting that hypoxia alters the
IGF/PI3K/Akt pathway activity. In agreement, Akt phosphorylation (active form) decreases after 4 hours of hypoxia.

CONCLUSION: Hypoxia activates muscle proteolysis and Atrogin-1 transcription, suggesting that the UP is involved in this process. The positive effects of insulin and the decrease in Akt activity during hypoxia support the notion that the IGF/PI3K/Akt pathway is defective during hypoxia.

\section{3}

\section{CPI-17 SILENCING IN HUMAN PRIMARY SMOOTH} MUSCLE CELLS AND ORGAN CULTURE BRONCHI

C Verreault, C Morin, N Godin, E Rousseau

FMSS, Université de Sherbrooke, Sherbrooke, Québec

The CPI-17 protein was described as a regulator of the MLC-Phosphatase and thought to be involved in the regulation of tone in various smooth muscles, including airway smooth muscles (ASM) cells. PKC-dependent phosphorylation of CPI-17 would maintain tone, without an effect on membrane potential. Eicosanoid, such as 14,15-EET, has recently been shown to reduce CPI-17-P and tone in human ASM (Morin and Rousseau, 2006). To study the role of CPI-17 in smooth muscle, transfections of a specific siRNA, designed against the human mRNA encoding for this protein, were performed on human primary pulmonary artery and bronchial SM cells. New F and R primers have also been designed. The siRNA was complexed with the X-TremeGene transfection reagent, whose low cytotoxicity and efficiency were determined by the use of a non-silencing rhodamine-tagged siRNA. It was found that most cultured cells were transfected by an optimized protocol (Godin and Rousseau, 2006). CPI-17 silencing was determined by RT-PCR as compared to control (untreated) and X-TremeGene treated cells, while Western blot analysis will assess the lower CPI-17 contents in total homogenates. Spectro-fluorometric measurements upon agonist challenges of control and siRNA-treated cells will assess the role of this target proteins for which no pharmacological inhibitor is available, yet. This work defines a model of RNA interference study on primary artery-SM cells, which will be extended to human ASM cells and organ culture bronchi in which a reverse permeabilization protocol will be used to transfect siRNA prior to tension measurements. Therefore, CPI-17 is likely to become a target of interest in the control of SM tone.

\section{4}

INTRACELLULAR LOCALIZATION OF 5-LIPOXYGENASE IN FRESHLY ISOLATED BLOOD EOSINOPHILS

F Chouinard, A Langlois, M Laviolette

Unité de recherche en pneumologie, Centre de recherche de I'Hôpital Laval, Institut universitaire de cardiologie et de pneumologie de l'Université Laval, Québec

BACKGROUND: 5-lipoxygenase (5-LO) is a key enzyme implicated in the biosynthesis of leukotrienes (LT). Intracellular localization of 5-LO determines its state of activation. In non-stimulated cells, 5-LO is located in the cytoplasm of neutrophils and eosinophils (Eo) and in the nucleus of alveolar macrophages and mast cells. After leukocyte stimulation, the 5-LO translocates to the nuclear membranes and initiates the synthesis of leukotrienes. 
HYPOTHESIS: Eo isolated from asthmatic subjects release more LTC4 than healthy subjects. Therefore, we hypothesize that in non-stimulated asthmatic Eo, the 5-LO is activated and located on the nuclear membranes. METHODS: 5-LO localization was assessed by Western blot and immunofluorescence on non-stimulated blood Eo from asthmatic and healthy subjects.

RESULTS: In both groups, we observed 5-LO into the nuclear fraction. CONCLUSION: The techniques used in this experience cannot discriminate if the 5-LO is located inside the nucleus or on nuclear membranes. Nevertheless, this result modifies the theory about the cytoplasmic localization of 5-LO into non-stimulated Eo.

\section{5}

\section{AIRWAY HYPERRESPONSIVENESS IN A MODEL OF ALLERGEN-INDUCED ASTHMA REFLECTS PERIPHERAL AIRWAY CHANGES}

S Siddiqui, T Jo, K Shalaby, M Bernabeu, JG Martin Meakins-Christie Laboratories, McGill University, Montreal, Quebec

RATIONALE: Corticosteroids have potent anti-inflammatory effects in asthma. We studied the effects of budesonide in an in vivo allergeninduced asthma model on pulmonary mechanics and inflammation. We partitioned the effects of repeated allergen challenges on airway responsiveness into large airway and peripheral lung compartments using a constant phase model and examined the modulation of changes by budesonide.

METHODS: $\mathrm{BN}$ rats were sensitized with ovalbumin (OVA) and assigned to one of three study groups: (i) Budesonide administration $(0.025 \mathrm{mg} / \mathrm{mL}$ ) and OVA challenge (Bud/OVA group); (ii) Saline as Vehicle and OVA challenge (Veh/OVA group); and (iii) Vehicle administration and sham (PBS) challenge (Veh/Sham group). Budesonide or vehicle was administered intranasally $24 \mathrm{~h}$ and $1 \mathrm{~h}$ before OVA or sham challenge. Treatments were repeated three times at 5 -day intervals. Two days after the third OVA challenge, airway responsiveness to aerosolized methacholine (Mch) was measured. The left lungs were formalin-fixed and stained using Periodic Acid Schiff staining to detect goblet cells in the airway epithelium.

RESULTS: There was a significant increase in total repiratory resistance and elastance in the Veh/Ova group in comparison to the Veh/Sham group at the highest dose of Mch administered: $64 \mathrm{mg} / \mathrm{mL} \quad(\mathrm{n}=6, \mathrm{p}<0.01)$. Increase in responsiveness between the ova-challenged and the shamchallenged groups was attributable to the peripheral airways because responsiveness of the central airways was not different. There was a significant difference in goblet cell numbers between the Veh/OVA group and Veh/Sham groups $(\mathrm{n}=5, \mathrm{p}<0.001)$ in the large airways $(>1 \mathrm{~mm})$ and a significant reduction in the Bud/OVA group $(n=5, p<0.001)$. There was a significant increase in smooth muscle mass around the peripheral airways in the Veh/Ova group when compared to the Veh/Sham group and this increase was reduced by budesonide $(n=6-17$ airways for each treatment, $\mathrm{p}<0.001)$.

CONCLUSIONS: Repeated allergen challenges cause airway hyperresponsiveness (AHR) in the sensitized rat. There is a decoupling in airway remodelling: although budesonide reduced large airway goblet cell metaplasia as well as peripheral smooth muscle mass, it was not successful in reducing AHR which appeared to result from changes in the peripheral airways.

Supported by Canadian Institutes of Health Research

\section{6}

CHARACTERIZATION OF MATRIX METALLOPROTEINASE 9 (MMP-9) EXPRESSION IN HUMAN BRONCHIAL SMOOTH MUSCLE CELLS (HBSMC)

\section{PG Tétreault, M Welman, K Maghni}

Research Center, Sacré-Cour Hospital of Montreal, Laboratory of Asthma Neuroimmunology, Université de Montréal, Montreal, Quebec

The MMPs are an enzyme family, which have an important role in extracellular matrix degradation. They are involved in tissue remodelling and have been implicated in airway remodelling in asthma. Pro-MMP-2 (gelatinase A) is expressed in human tracheal SMC (HTSMC), and its active form is involved in HTSMC proliferation. However, the expression and the role of other gelatinases and their endogenous inhibitors in HBSMC are mostly unknown.

AIM: To determine the expression and localization of MMP-9 (gelatinase B) in HBSMC, and its level of expression as a function of cell phenotype (synthetic/proliferative vs contractile).

METHODOLOGY: HBSMC were purchased from Cambrex. Gelatinase activities and the expression of MMP-9 were determined respectively by zymography and Western blot (WB). Cellular localization of MMP-9 was determined by epifluorescence microscopy with deconvolution analysis. Levels of cell confluency (30,60 and 90\%) were used to define phenotype. RESULTS: Zymography analysis indicated gelatinase activities at $67 \mathrm{kDa}$. WB indicated that MMP-9 is expressed. Surprisingly, the MMP-9 active truncated form of $67 \mathrm{kDa}$ was detected. Blocking MMP activities in cell lysates with the inhibitor GM6001 did not lead to the detection of the $92 \mathrm{kDa}$ pro-MMP-9. We found that MMP-9 is localized at the cell membrane. Finally, we showed that the expression of MMP-9 decreases when HBSMC switch from the synthetic/proliferative toward the contractile phenotype.

CONCLUSION: Our study shows that HBSMC express MMP-9, but as the active fragment of $67 \mathrm{kDa}$. The role of MMP-9 in HBSMC function remains to be determined.

Supported by the Institut de Recherche en Santé et Sécurité au Travail (IRSST)

\section{7}

\section{TNF EXPRESSION IN UVULAR TISSUES DIFFERS BETWEEN SNORERS AND APNEIC PATIENTS}

\section{Loubaki, J Chakir, F Sériès}

Centre Recherche, Hôpital Laval, Institut Universitaire de Cardiologie et de Pneumologie de I'Université Laval, Québec

BACKGROUND: Obstructive sleep apnea (OSA) is an increasingly well-recognized disease characterized by periodic collapse of the upper airway (UA) during sleep. UA narrowing increased UA collapsibility, disturbances in reflexly mediated adaptations of UA muscles neuromuscular activity and pharyngeal inspiratory muscle dysfunction may contribute to the occurrence of upper airway occlusion during sleep. Pro-inflammatory cytokines such as TNF and IL-6 are elevated in serum of OSA patients and have been proposed as mediators of muscle weakness. TNF has been shown to affect mice and rabbit diaphragm contractility in vivo.

OBJECTIVE: To measure the expression of TNF in uvular tissue of nonapneic snorers and apneic patients.

METHODS: Twenty-four patients who underwent an UPPP were enrolled in this study and distributed into three groups. The first group $(\mathrm{N}=5)$ was composed of non-apneic snorers. The second group $(\mathrm{N}=11)$ was composed of patients with OSA (OSA1) whose body mass index was similar to snorers. The third group $(\mathrm{N}=8)$ consisted of patients with severe OSA (OSA2) who could not be associated with non-apneic snorers. After surgery, the resected tissues were immediately divided into two sections (proximal and distal) and then frozen for immunohistochemistry and immunoblotting with anti-TNF.

RESULTS: Immunostaining of the frozen sections showed that TNF is highly expressed in the epithelium of the uvula and in the musculus uvulae (MU). We find no significant difference between our three groups for MU staining. Immunoblotting of total proteins from proximal sections of uvula $(\mathrm{N}=3)$ revealed that the expression of TNF precursor was two times higher in OSA2 $(15,33 \pm 4.04 \mathrm{AU})$ than in OSA1 $(13,33 \pm 8.08 \mathrm{AU})$ and snorers $(25,33 \pm 9.29 \mathrm{AU})$.

CONCLUSION: TNF seems to be more highly expressed in uvula tissues of severe apneic patients than in snorers. This increase of TNF may play a role in the function of uvula in sleep apnea. 


\section{8}

LONG TERM EFFECTS OF NEONATAL CAFFEINE ON THE HYPOXIC RESPIRATORY CHEMOREFLEX OF RAT

\section{G Montandon, R Kinkead, A Bairam}

Centre de recherche du CHUQ, Unité de Périnatalogie, Hôpital Saint-François d'Assise, Université Laval, Québec

OBJECTIVES: Caffeine, an adenosine receptor antagonist, is widely used in the clinic as a respiratory stimulant to treat apnea of prematurity. The aims of this study were to determine if neonatal caffeine has long lasting influences on the hypoxic respiratory chemoreflex of the adult rat and whether caffeine treatment modifies respiratory sensitivity to hypoxia.

METHODS: Caffeine-treated pups received caffeine $(15 \mathrm{mg} / \mathrm{kg})$ each day from postnatal day 3 to 12 by gavage, whereas controls received water. The hypoxic ventilatory response $\left(12 \%\right.$ of $\left.\mathrm{O}_{2}\right)$ was evaluated using whole-body plethysmography in control and caffeine-treated adult male rats. Phrenic nerve response to hypoxia (12\%) was also measured in anesthetized adult male rats from both groups. Finally, adenosine $A_{1}$ and $A_{2 A}$ receptor mRNA levels were assessed in the striatum and the carotid bodies by RT-PCR in both groups.

RESULTS: In caffeine-treated rats, the breathing frequency response to hypoxia was higher than in controls during the 10 first minutes of hypoxia. The phrenic nerve burst frequency response to hypoxia was also increased in caffeine-treated rats during the first minute of the response. Finally, neonatal caffeine increased mRNA levels of adenosine $A_{2 A}$ receptors in the carotid bodies only.

CONCLUSION: This study demonstrates that caffeine treatment during the neonatal period induces long lasting increases of the hypoxic respiratory chemoreflex, probably by increasing excitatory adenosine $A_{2 \mathrm{~A}}$ receptors in the carotid body, and that these changes persist until adulthood. This work was supported by the CIHR and by a scholarship from the Jeanne-etJean-Louis-Levesque Perinatalogy Chair (GM)

\section{9}

ÉVALUATION DE LA SUSCEPTIBILITÉ À LA DÉSATURATION ARTÉRIELLE EN OXYGÈNE $\left(\mathrm{dSaO}_{2}\right)$ ET AU MAL AIGU DES MONTAGNES (MAM) AU COURS DE L'ASCENSION DU KILIMANDJARO

P Mayer, A Delage, C Poirier, V Jobin, F Bellemare

Laboratoire du sommeil, Centre Hospitalier de l'Université de Montréal (CHUM)-Hôtel-Dieu, Montréal, Québec

THÉORIE: Le mal aigu des montagnes (MAM) atteint 25-85\% des individus séjournant à une altitude supérieure à $2500 \mathrm{~m}$. Une réponse ventilatoire inadéquate à l'hypoxie a été suggérée comme étant un des facteurs prédisposants. Cependant, des résultats conflictuels existent sur la capacité de prédire la désaturation en oxygène $\left(\mathrm{dSaO}_{2}\right)$ en altitude et la susceptibilité au MAM à partir de tests faits au niveau de la mer.

MÉTHODOLOGIE: Pour étudier la susceptibilité à la $\mathrm{dSaO}_{2}$ en altitude et au MAM des tests en hypoxie poikilocapnique $\left(11 \% \mathrm{O}_{2}\right.$, balance $\mathrm{N}_{2}$, altitude simulée de $5000 \mathrm{~m}$ ) ont été effectués chez 10 volontaires sains avant l'ascension soit (1) pour une période de 20 minutes au repos en décubitus dorsal (test $\mathrm{R}$ ) et (2) lors d'un effort progressif jusqu'à $50 \%$ de la $\mathrm{VO}_{2} \mathrm{Max}$ (test $\mathrm{E}$ ). Au cours de l'ascension, la $\mathrm{SaO}_{2}$ a été enregistrée en continu par réflectométrie frontale (PalmSat 2500, senseur 8000R, Nonin Medical Inc, MN, USA). Le MAM a été évalué quotidiennement à l'aide du questionnaire standardisé du Lac Louise.

RÉSULTATS: $\mathrm{La} \mathrm{SaO}_{2}$ moyenne à l'effort et la $\mathrm{SaO}_{2}$ moyenne nocturne ont diminué de façon linéaire et comparable avec l'altitude $>3000 \mathrm{~m}$ et corrélaient de façon significative avec le score moyen de MAM $\left(\mathrm{r}^{2}=0.85\right)$. Lors de la dernière journée d'ascension, les valeurs de $\mathrm{SaO}_{2}$ moyenne à l'effort (altitude $5300 \mathrm{~m}$ ) et nocturne (altitude $5600 \mathrm{~m}$ ) étaient respectivement de $69.7 \pm 5.9 \%$ et $68.7 \pm 5.2 \%$. Le test $\mathrm{R}$ a prédit la valeur $\mathrm{de} \mathrm{SaO}_{2}$ nocturne moyenne avec une précision de $102.5 \pm 9.9 \%$ (écart $89-117 \%$ ) comparativement à $93.0 \pm 13.7 \%$ (écart $78-113 \%$ ) pour le test $\mathrm{E}$. La valeur de $\mathrm{SaO}_{2}$ moyenne à l'effort a été prédite avec une précision de $101.8 \pm 12.1 \%$ (écart 80-116\%) par le test $\mathrm{R}$ comparativement à $93.7 \pm 8.5 \%$ (écart $74-106 \%$ ) pour le test $\mathrm{E}$.

CONCLUSION: En accord avec les données préexistantes, il existe, pour notre groupe, une corrélation étroite entre le score du MAM et la sévérité de la désaturation en oxygène nocturne et à l'effort en altitude. Les tests au repos (R) et à l'effort (E) faits en hypoxie poikilocapnique au niveau de la mer sont adéquats pour évaluer la susceptibilité individuelle à la $\mathrm{dSaO}_{2}$ et, conséquemment, au MAM pour un niveau comparable d'hypoxie hypobarique.

Ce travail a été subventionné par le Laboratoire Médical Biron

\section{0}

\section{RESPONSE OF THE GENIOGLOSSUS TO TRANSCRANIAL MAGNETIC STIMULATION IN OBSTRUCTIVE SLEEP APNEA PATIENTS AND NORMALS}

\section{$\underline{\text { F Sériès }}^{1}$, W Wang ${ }^{2}$, T Similowski ${ }^{3}$}

${ }^{1}$ Institut Universitaire de Cardiologie et de Pneumologie de I'Université Laval, Québec; ${ }^{2}$ China Medical University, Shenyang, China; ${ }^{3}$ Service de Pneumologie, Hôpital Pitié-Salpêtrière, Paris, France

INTRODUCTION: Upper airway patency is modulated by tonic and inspiratory-related phasic activities of dilator muscles. During wakefulness, these activities are higher in obstructive sleep apnea (OSA) patients than in normal. This study aims at comparing genioglossus (GG) and diaphragm (Dia) cortico-motor responses to transcranial magnetic stimulation (TMS) during wakefulness between OSA and normal subjects. METHODS: Motor evoked potential (MEP) of GG and Dia were recorded with TMS applied at vertex $(\mathrm{Cz})$ and dominant-sided antero-lateral $(\mathrm{AL})$ area in 13 OSA and 8 age and body mass index-matched normal subjects. Stimuli were applied $1 \mathrm{~s}$ after inspiratory onset with and without resistance $($ Insp $+\mathrm{R}$, Insp) and $0.5 \mathrm{~s}$ after expiratory onset with and without maximal tongue protrusion (Exp+P, Exp). Motor threshold (MT) (lowest stimulator output that elicited a $50 \mu \mathrm{V}$ MEP response on at least $3 / 5$ stimulations) was measured in each condition.

RESULTS: Dia and GG responses to TMS were linked in $84 \%$ and $52 \%$ of twitches in OSA and in normal respectively $(\mathrm{P}<0.0001)$. In OSA, GG MEP latency was less in Exp+P than in other conditions in Cz. Such difference was not observed in normal. A significant relationship was found between the apnea-hypopnea index and the latency and amplitude of GG MEP responses in OSA patients $(r=0.66, \mathrm{P}=0.01)$. The amplitude of genioglossus response increased during tongue protrusion in both groups and during inspiration in OSA patients only. No difference in Dia MEP amplitude was seen between the different respiratory conditions. In OSAS, the MT GG was systematically lower than that of Dia in any TMS site and respiratory condition (tidal expiration in $\mathrm{Cz} 72.9 \pm 2.8 \%$ and $80.4 \pm 3.2 \%$ respectively, $\mathrm{P}<0.01$ ). In controls this difference was only found in $\mathrm{Cz}$ during tongue protrusion.

CONCLUSIONS: 1) GG and Dia cortico-motor responses to TMS are differently influenced by respiratory conditions in OSAS patients and normal, 2) this response varies with the frequency of nocturnal breathing disorders.

Supported by CIHR grant MT 13768

\section{1}

\section{IMPACT OF SIBUTRAMINE ON CARDIAC AUTONOMIC NERVOUS SYSTEM IN OBESE PATIENTS WITH OBSTRUCTIVE SLEEP APNEA SYNDROME}

\section{IMartin, A Ferland, S Croteau, F Sériès, D Page, P Poirier}

Centre de recherche de l'Hôpital Laval, Quebec

OBJECTIVES: To investigate the impact of sibutramine-induced weight loss on cardiovascular autonomic function in obese patients with obstructive sleep apnea syndrome (OSAS).

METHODS: Twenty-two obese subjects (BMI of $35.1 \pm 1.9 \mathrm{~kg} / \mathrm{m}^{2}$ ) with OSAS underwent a 1-year sibutramine treatment $(10 \mathrm{mg}$ or $15 \mathrm{mg}) \mathrm{com}$ bined with dietary and physical exercise recommendations. Fasting blood samples were taken, blood pressure was measured using a 24-hour monitoring and heart rate variability (HRV) was derived from a 24-hour Holter monitoring, all performed at two occasions (baseline and after 1 year). Using frequency domains, power in the very-low frequency (VLF), low frequency (LF), LF/high frequency (HF) was calculated. Using time domains, 
the mean NN, the SDNN, the SDANN, the rMSSD and the pNN50 indices were determined.

RESULTS: After a 1-year treatment of sibutramine, there were a $5 \%$ decrease in weight, a 7\% reduction in waist circumference and an increase of HDL-cholesterol levels ( $1.10 \pm 0.06$ vs $1.27 \pm 0.07 \mathrm{mmol} / \mathrm{L})$ from baseline (all $\mathrm{P}<0.001)$. No significant difference was observed in mean systolic and diastolic blood pressure, resting heart rate, fasting glucose, total cholesterol, LDL-cholesterol and plasma triglycerides in comparison with baseline. Following weight loss, there were no significant differences in the indices of HRV, such as VLF, HF, LF and the LF/HF ratio. Furthermore, no changes were observed in the RR interval (mean NN), SDNN, SDANN indices and the cardiac parasympathetic modulation (HF, rMSSD and pNN50).

\begin{tabular}{lccc} 
& Baseline & 1-year & P \\
\hline VLF $\left(\mathrm{ms}^{2}\right)$ & $6.5 \pm 0.8$ & $6.6 \pm 0.7$ & 0.99 \\
LF $\left(\mathrm{ms}^{2}\right)$ & $5.8 \pm 0.9$ & $5.9 \pm 0.8$ & 0.48 \\
HF $\left(\mathrm{ms}^{2}\right)$ & $4.4 \pm 0.9$ & $4.5 \pm 0.9$ & 0.68 \\
Ratio LF/HF & $1.5 \pm 0.5$ & $1.4 \pm 0.4$ & 0.88 \\
Mean NN & $742.0 \pm 96.0$ & $778.0 \pm 129.0$ & 0.38 \\
SDNN & $119.0 \pm 38.5$ & $126.1 \pm 41.9$ & 0.80 \\
SDANN & $106.8 \pm 32.5$ & $110.9 \pm 42.4$ & 0.93 \\
rMSSD & $25.7 \pm 10.1$ & $24.5 \pm 9.7$ & 0.59 \\
pNN50 & $6.8 \pm 6.1$ & $5.8 \pm 6.5$ & 0.15 \\
\hline
\end{tabular}

CONCLUSION: These results suggest that sibutramine induced weight loss with increment in HDL level in patients with OSAS. However, there was no improvement in autonomic cardiac modulation, normally associated with a significant weight loss.

Supported by Abbott laboratories

\section{2}

\section{CONSÉQUENCES HÉMODYNAMIQUES DE L'APPLICATION DE LA VENTILATION LIQUIDIENNE TOTALE (VLT) DANS UN MODÈLE EXPÉRIMENTAL DE SYNDROME DE DÉTRESSE RESPIRATOIRE AIGUE (SDRA) CHEZ L'AGNEAU NOUVEAU-NÉ (RÉSULTATS PRÉLIMINAIRES)}

L Lebon ${ }^{1}$, R Robert ${ }^{2}$, H Walti ${ }^{1,3}$, O Lesur ${ }^{1}$, JP Praud ${ }^{1,3}$, P Micheau ${ }^{2}$

${ }^{1}$ Département de Physiologie; ${ }^{2}$ Département de Génie Mécanique; ${ }^{3}$ Département de Pédiatrie, Université de Sherbrooke, Sherbrooke, Quebec

INTRODUCTION: La VLT est un mode de ventilation alternatif prometteur dans la prise en charge respiratoire du SDRA. Cependant, les effets hémodynamiques de la VLT restent controversés

OBJECTIF: Évaluer par un essai randomisé et contrôlé les effets hémodynamiques de la VLT dans un modèle ovin néonatal de SDRA.

MÉTHODES: Les effets de la VLT ( $\mathrm{n}=11)$ ont été comparés à ceux de la ventilation gazeuse $(V G)(n=8)$ dans un modèle de SDRA obtenu par instillation intratrachéale d'HCl chez l'agneau nouveau-né à terme anesthésié et curarisé. Des cathéters étaient placés dans la fémorale et la jugulaire droite (Swan-ganz) pour les mesures de l'hémodynamique systémique et pulmonaire par thermodilution (PICCO, Pulsion Medical System). Après lavage, les paramètres hémodynamiques, les échanges gazeux et l'équilibre acido-basique ont été comparés entre les deux groupes toutes les 30 min sur une période de $240 \mathrm{~min}$ avec une $\mathrm{FiO}_{2}$ de 1.0. Les animaux étaient ensuite sacrifiés et les poumons prélevés pour la mesure du rapport poids humide/poids sec et l'analyse histologique.

RÉSULTATS: La ventilation en VMC et VLT a permis d'améliorer les échanges gazeux par rapport aux données postlavage et d'atteindre les objectifs fixés. L'amélioration de l'oxygénation est plus significative en VG. Les données hémodynamiques disponibles montrent une diminution transitoire de la pression artérielle moyenne par diminution du débit cardiaque. Cette diminution transitoire n'est pas compensée par une augmentation de la fréquence cardiaque ou l'augmentation des résistances vasculaires systémiques.

CONCLUSION: Dans ce modèle la VLT assure des échanges gazeux adéquats sans effets majeurs sur l'hémodynamique.
13

\section{ÉTUDE DE L'ADAPTATION RESPIRATOIRE LORS DU SEVRAGE AUTOMATISÉ DE LA VENTILATION MECANIQUE CHEZ L'ENFANT}

A Monir, P Jouvet, V Payen, M Santschi, J Lacroix

Centre de recherche, $\mathrm{CHU}$ Sainte-Justine, Montréal, Québec

OBJECTIF: Décrire l'influence et l'adaptation de la fréquence respiratoire (Fr), du volume courant $(\mathrm{Vt})$ et du $\mathrm{CO}_{2}$ expiré chez l'enfant, lors du sevrage de l'assistance respiratoire par un protocole automatisé en boucle fermée.

MÉTHODES: 23 enfants âgés entre 1 et 17 ans, ventilés en mode aide inspiratoire (AI) avec le protocole de sevrage automatisé : Automedon/PS, ont été étudiés. A partir des données cliniques enregistrées en continu ( $\mathrm{Fr}$, $\mathrm{Vt}, \mathrm{CO}_{2}$ expiré), la ventilation était classifiée comme normale $(\mathrm{VN})$ ou anormale (VNA) selon leurs valeurs et s'accompagnait d'un ajustement du niveau d'AI. Nous avons étudié l'influence respective des trois paramètres sur les passages de VA à VNA et VNA à VA, ainsi que les modifications de $\mathrm{Fr}, \mathrm{Vt}$ et $\mathrm{CO}_{2}$ expiré lors d'une diminution de l'AI de $2 \mathrm{cmH}_{2} \mathrm{O}$ alors que l'enfant restait en $\mathrm{VN}$ dans les 20 minutes suivantes.

RÉSULTATS: La médiane de maintien en VN chez les 23 enfants était de $95,7 \%$. Avec une médiane de 11 changements de classification par patient, la Fr entraînait le changement dans $45.1 \%$, le $\mathrm{Vt}$ dans $47.3 \%$ et le $\mathrm{CO}_{2}$ expiré $1.6 \%$ des cas. Lors de la baisse de $2 \mathrm{~cm} \mathrm{H}_{2} \mathrm{O}$ d'AI avec maintien en $\mathrm{VN}$, le $\mathrm{Vt}$ diminuait significativement de $0.5 \mathrm{ml} / \mathrm{kg}$, sans variation significative de $\mathrm{Fr}$ ni du $\mathrm{CO}_{2}$ expiré à 2 et $20 \mathrm{~min}$.

CONCLUSION: Lors du sevrage en mode aide inspiratoire à l'aide du protocole automatisé Automedon/PS, ce sont $\mathrm{Fr}$ et $\mathrm{Vt}$, en proportion identique, qui influencent le changement de classification respiratoire. L'analyse d'un plus grand échantillon d'enfants devrait permettre d'évaluer d'évaluer l'intérêt d'ajouter la tendance évolutive des paramètres à l'algorithme de Automedon/PS.

\section{4}

IMPLANTATION D'UN PROGRAMME DE SOINS INTEGRES POUR LES PATIENTS MPOC ET EFFET SUR L'UTILISATION DES SERVICES DE SANTÉ

Favreau $H$, Lavoie KL, Julien M, Labrecque $M$

Pneumologie, Psychologie, Hôpital Sacré-Cœur de Montréal, UQAM, Montréal, Québec

BACKGROUND: La maladie pulmonaire obstructive chronique (MPOC) est la $4^{\mathrm{e}}$ cause de décès en Amérique du Nord. Elle est associée à une morbidité significative, incluant un taux élevé de visites à l'urgence et d'hospitalisations et une diminution de la qualité de vie chez les patients. Les diminutions de la fréquence et de la sévérité des exacerbations de la MPOC nécessitent une approche multidisciplinaire adaptée au besoin du patient. La présente étude évalue l'implantation d'un programme de soins intégrés et son effet sur l'utilisation des soins de santé chez les patients MPOC.

MÉTHODE: Un programme de soins intégrés pour les patients MPOC a été implanté au service de pneumologie de l'Hôpital Sacré-Cœur de Montréal (HSCM). Une intervenante pivot complètement dédiée à la clientèle MPOC a évalué systématiquement la condition des patients MPOC qui se sont présentés à l'urgence ou qui ont été hospitalisés et les a référé selon leurs besoins spécifiques dans un ou plusieurs des programmes disponibles au sein du CSSS soient : suivi téléphonique de l'HSCM par une infirmière ressource ( programme RESPIR), enseignement de groupe, réadaptation respiratoire, aide à la cessation tabagique, suivi par les CLSC du territoire ou le service régionale des soins à domicile (SRSAD). Ont été exclus de l'étude les patients avec une comorbidité sévère, les patients provenant d'un CHSLD et les patients bénéficiant déjà du programme RESPIR de l'HSCM. L'utilisation des soins de santé (comprenant visites à l'urgence et hospitalisations) a été mesurée par une entrevue téléphonique du patient et la revue de son dossier médical sur un échantillon de 100 patients MPOC 12 mois pré et post le $1^{\text {er }}$ service reçu compris dans le programme de soins intégrés. Cet échantillon a été comparé à un groupe contrôle formé de patients MPOC d'un $\mathrm{CH}$ régional en soins primaires n'ayant reçu aucun de ces services. Des analyses ANOVA one-way à mesures répétées ont été utilisées.

RÉSULTATS: IMPLANTATION: Ce programme a permis de cibler 
pour l'année 2003-2004 100\% des patients MPOC éligibles selon les critères d'exclusion ( $\mathrm{N}=295)$, parmi eux $84 \%$ ont été référés dans au moins un des programmes, pour l'année 2004-2005 94\% des patients MPOC $(\mathrm{N}=263)$ ont été ciblés et $84 \%$ référés à un ou plusieurs programme(s).

EFFET: Le nombre et la durée moyenne d'hospitalisations ont été significativement réduits 12 mois post intervention comparativement à 12 mois pré intervention (respectivement : $53 \%$ et $63 \%, \mathrm{p}<.01$ ), alors que pour le groupe contrôle il n'y a pas eu de diminution significative ( $>$.05). Toutefois l'effet du programme a été plus important chez les femmes (respectivement : $79 \%$ et $71 \% ; \mathrm{p}<.01$ ) comparativement aux hommes (respectivement: $28 \%$ et $58 \% ; \mathrm{p}<.01$ ).

CONCLUSION: Les résultants indiquent que l'approche multidisciplinaire de soins intégrés grâce à l'ajout d'une infirmière pivot dédiée à la clientèle MPOC est réussie. De plus, ce programme d'intervention a permis une diminution de la fréquence et de la durée des hospitalisations reliées aux exacerbations de la MPOC, ces effets ont été plus importants chez les femmes. Cette différence d'efficacité reliée au sexe mérite d'être explorée.

\section{5}

\section{SWINE CONFINEMENT BUILDINGS: THE EFFECTS OF SWINE AIR AND DUST ON AIRWAY SMOOTH MUSCLE}

A Demanche, J Bonloke, MJ Beaulieu, E Israel-Assayag, Y Cormier Centre de Recherche de l'Hôpital Laval, Université Laval, Québec

RATIONALE: Swine confinement workers are exposed to various contaminants which include dust, endotoxin and bacteria. These agents can cause airway inflammation and bronchoconstriction. This study has been performed to evaluate if the bronchoconstriction effects of swine air and dust are mediated by endotoxin and directly on airway smooth muscles.

METHODS: Mice tracheal rings were isolated and mounted isometrically in organ baths. Tracheas, with or without epithelium, were attached to a force transducer and tension was recorded. Concentrated swine building air $68 \mathrm{EU} / \mathrm{ml}$ (endotoxin unit/mg) or sediment dust extract at $0.01 \mathrm{~g} / \mathrm{ml}$ were then added to the baths for 20 minutes, cumulative doses of methacholine added and tracheal smooth muscle contraction was measured. The direct role of LPS was assessed by removing endotoxin from the air concentrates with an END-X B15 endotoxin affinity resin.

RESULTS: Swine air and dust caused contraction of tracheal smooth muscles by 26 and $20 \%$ respectively of maximal methacholine contraction. Removal of epithelium did not affect the contractile effects. LPS alone and LPS with peptydoglycans did not induce contraction. However, when endotoxin was removed from swine air concentrates, it partially lost its contractile effect by $24 \%$.

CONCLUSION: Concentrated swine air and dust have direct effects on airway smooth muscles. This effect is partially due to LPS but a synergy with other organic particles present in the environment of swine confinement buildings is required and the nature of these particles needs to be identified.

\section{6}

\section{ASSOCIATION BETWEEN OBSTRUCTIVE SLEEP APNEA AND} GESTATIONAL HYPERTENSION

KA Champagne ${ }^{1,2}$, K Schwartzman $^{1,2}$, P Barriga $^{3}$, L Morin ${ }^{4}$, L Opatrny', A Mallozzi ${ }^{4}$, A Benjamin ${ }^{4}$, A Olah ${ }^{5}$, N Naor ${ }^{5}$, K Riches ${ }^{5}$, C Barber ${ }^{5}$, RJ Kimoff ${ }^{1}$

${ }^{1}$ Department of Medicine; ${ }^{2}$ Respiratory Epidemiology and Clinical Research Unit, McGill University Health Center; ${ }^{3}$ Santa Cabrini; ${ }^{4}$ Department of Obstetrics, McGill University Health Center; ${ }^{5}$ McGill University Health Center, Montreal, Quebec

BACKGROUND: Snoring, a marker of obstructive sleep apnea (OSA) is a newly described risk factor for gestational hypertension. OSA is a risk factor for hypertension in the non-pregnant population.

OBJECTIVE: Test the hypothesis that the proportion of women with OSA is higher in those with than without gestational hypertension.

METHODS: Case-control study of pregnant women with and without hypertension developing in pregnancy, stratified for gestational age. Complete overnight unattended polysomnography including nasal pressure was performed with manual scoring of sleep-wake state and respiratory events. OSA was defined as an apnea-hypopnea index $(\mathrm{AHI}) \geq 15$ events/h of sleep. RESULTS: 17 cases and 33 controls were studied. Controls were recorded at a mean gestational age of 32.4 SD 4.6 weeks and had a mean AHI 18.2 SD 12.2. Cases were studied at a mean of 33.4 SD 4.7 weeks gestation and had a mean AHI 38.6 SD 36.7. OSA was present in $82 \%$ (14/17) of subjects with gestational hypertension vs $45 \%$ (17/33) of normotensive controls. The crude odds ratio of having OSA given gestational hypertension was 5.6 (95\% CI 1.4-23.2) and was 7.5 (95\% CI 3.5-16), p<0.0001 when adjusted for gestational age, maternal age, pre-gravid body mass index, parity and gravida status.

CONCLUSIONS: Women developing gestational hypertension are much more likely to have OSA during pregnancy than those who remain normotensive. Whether treatment of OSA influences maternal and fetal outcomes remains to be determined.

Funded by FRSQ, MUHC RI, RCPSC

\section{7}

SELF-ADMINISTERED PRESCRIPTIONS OF ORAL STEROIDS AND ANTIBIOTICS IN COPD. ARE WE DOING MORE HARM THAN GOOD?

$\underline{\text { L Beaulieu-Genest }}{ }^{1}$, D Chrétien ${ }^{2}$, F Maltais ${ }^{1,3}$, JG Parent ${ }^{2}$, Y Lacasse ${ }^{1,3}$

${ }^{1}$ Centre de recherche, Centre de pneumologie, Hôpital Laval, Institut universitaire de cardiologie et de pneumologie de I'Université Laval; ${ }^{2}$ Clinique MPOC, Hôpital Saint-François d'Assise, Centre Hospitalier Universitaire de Québec; ${ }^{3}$ Clinique MPOC, Hôpital Laval, Institut universitaire de cardiologie et de pneumologie de l'Université Laval, Québec

BACKGROUND: Patients with chronic obstructive pulmonary disease (COPD) are often given a prescription for a short course of oral steroids and antibiotics appropriate for self-administration during an acute exacerbation. The main objective of this study was to determine the impact of such prescriptions on medical care utilization, and steroids and antibiotics intake. METHODS: This retrospective cohort study included patients with moderate to severe COPD participating in a self-management program. We compared the number of unplanned medical visits (including hospitalizations) and the utilization of systemic steroids (number of short courses, number of days on treatment) and antibiotics (number of treatments) over a period of 6 months following registration to the program in patients who received such a prescription and those who did not. Data were collected from hospital and community pharmacy files.

RESULTS: A total of 89 patients were included; 46 received a selfadministered prescription. During the study period, we found no difference between the two groups in the number of unplanned medical visits. However, we observed small but significant differences in the number of short courses of Prednisone $(p=0,018)$ and antibiotics $(p=0,006)$. This translated in an important difference in the number of days on steroids over the same period ('Prescription' group: 26; controls: $8 ; \mathrm{p}=0,005$ ).

CONCLUSION: Self-administered prescriptions may increase steroids and antibiotics utilization in patients with moderate to severe COPD.

\section{8}

EFFECTS OF CENTRAL AND TOTAL BODY FAT ON ASTHMA MORBIDITY

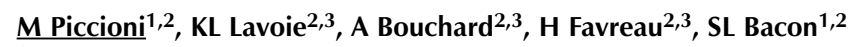
Department of Exercise Science, Concordia University;

2Department of Pneumology, Hôpital du Sacré-Coeur de Montreal; ${ }^{3}$ Department of Psychology, UQAM, Montreal, Quebec

BACKGROUND: Recently total body fat has been associated with increased asthma severity, poorer asthma control and worse quality of life. However the role central adiposity and the comparison of central adiposity to total body fat in the prediction of asthma morbidity is unknown.

PURPOSE: To compare central adiposity with total body fat in the prediction of asthma morbidity, specifically asthma control and asthma quality of life. 
METHODS: Thirty-four patients with physician diagnosed asthma (Mean $(\mathrm{SD})$ age $=44(14)$ years, $41 \%$ male) completed the asthma control (ACQ) and quality of life questionnaires (AQLQ) and provided sociodemographic information and had their waist and hip circumference measured. Linear model analyses were conducted to assess the relationship between adiposity and asthma morbidity. Separate models were run for the total and each subscale of the ACQ and the AQLQ, entering body mass index, waist circumference and waist-to-hip ratio, together, controlling for age, sex and asthma severity.

RESULTS: From the ACQ, only the waist-to-hip ratio was significantly related to waking symptoms $(\beta=-12.25, \mathrm{p}=.037)$ and total control $(\beta=-8.51, p=.026)$ and tended to be related to activity limitations $(\beta=-10.22, p=.099)$, wheezing $(\beta=-14.46, p=.064)$ and bronchodilator use ( $\beta=-10.63, p=.082)$. Waist-to-hip was not related to any other ACQ measure and neither body mass index nor waist circumference was related to any of the ACQ measures. For quality of life, body mass index was significantly related to activity limitations $(\beta=-0.20, p=.050)$, environmental stimuli $(\beta=-0.31, p=.020)$ and total AQLQ score $(\beta=-0.20, p=.050)$. $\mathrm{BMI}$ was not related to emotional distress or symptoms. Neither waist circumference nor waist-to-hip ratio was correlated to any AQLQ measures.

CONCLUSIONS: These results suggest that central adiposity plays a significant role in asthma control independent to total body fat, such that greater central adiposity is associated with better control. In contrast to asthma quality of life, increasing total body fat is significantly associated with poorer quality of life independent of central adiposity. Further research is needed in larger samples to establish mechanisms by which central adiposity and total body fat influences these measures of asthma morbidity.

\section{9}

\section{INTERPRETING CHANGES IN ENDURANCE SHUTTLE WALKING PERFORMANCE}

C Brouillard ${ }^{1}$, V Pepin ${ }^{2}$, S Singh ${ }^{3}$, S Revill ${ }^{4}$, Y Lacasse ${ }^{1}$, F Maltais ${ }^{1}$

${ }^{1}$ Centre de recherche, Hôpital Laval; ${ }^{2}$ Centre de recherche, Hôpital du Sacré-Coeur de Montréal, Montréal, Québec; ${ }^{3}$ Pulmonary Rehabilitation Research Group, Institute for Lung Health, Department of Respiratory Medicine and Thoracic Surgery, Glenfield Hospital, Leicester, United Kingdom; ${ }^{4}$ Sherwood Forest Hospitals, Ashfield Community Hospital, Kirby-in-Ashfield, Notts, United Kingdom

RATIONALE: The endurance shuttle walk has recently been shown to be highly responsive to both bronchodilation and pulmonary rehabilitation. The degree to which changes in endurance shuttle walking performance are perceptible to patients is unknown.

OBJECTIVE: To evaluate the relationship between objective and subjective measures of change in endurance shuttle walking performance.

METHODS: 129 comparison points were obtained from 69 patients with $\mathrm{COPD}\left(\mathrm{FEV}_{1}: 47 \pm 16 \%\right)$ who completed two or more endurance shuttle walking tests as part of a bronchodilation study. Patients were asked to rate their performance of the day in comparison to their previous performance on a 7 point scale ranging from -3 (large deterioration) to +3 (large improvement). These ratings were related to changes in walking distance and endurance time, expressed both as delta and percent change. Results: Patient ratings of change were significantly correlated with delta walking distance $(r=0.44, p<0.001)$, delta endurance time $(r=0.46, p<0.001)$, percent change in walking distance $(\mathrm{r}=0.54, \mathrm{p}<0.001)$, and percent change in endurance time $(\mathrm{r}=0.55, \mathrm{p}<0.001)$. Deteriorations in walking performance were perceived in $34 \%$ of cases, while improvements were detected in $81 \%$ of cases.

CONCLUSION: Changes in endurance shuttle walking performance, especially improvements, are well perceived by patients with COPD. From this set of data, it should be possible to identify the smallest change in walking performance with a high likelihood of being perceived by the patients (MCID).

\section{0}

\section{SYMPTÔME LIMITANT L'EXERCICE ET RÉPONSE AUX BRONCHODILATATEURS DANS LA MALADIE PULMONAIRE OBSTRUCTIVE CHRONIQUE}

D Deschênes ${ }^{1}$, V Pepin ${ }^{1}$, D Saey ${ }^{2}$, P LeBlanc ${ }^{1}$, F Maltais $^{1}$

${ }^{1}$ Centre de recherche, Hôpital Laval, Institut Universitaire de

Cardiologie et de Pneumologie de l'Université Laval, Québec;

${ }^{2}$ Respiratory Muscle Research Unit, Laboratory of Pneumology,

Katholieke Universiteit Leuven, Leuven, Belgium

La présence de fatigue contractile du quadriceps à l'exercice chez les patients souffrant de MPOC diminue la probabilité que la bronchodilatation améliore le temps d'endurance lors d'un exercice à charge constante. L'objectif de cette étude était d'évaluer si la perception de la dyspnée et de la fatigue des jambes pouvait prédire la réponse au bronchodilatateur dans cette population. Soixante-huit patients MPOC ont accompli deux épreuves d'endurance sur ergocyle ou deux épreuves d'endurance de marche-navette

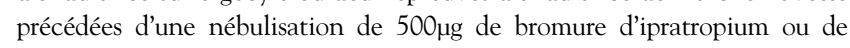
placebo. Les variations du VEMS et du temps d'endurance suite à la bronchodilatation ont été mesurées ainsi que les changements de la force musculaire du quadriceps après l'exercice. La dyspnée et la perception de la fatigue des jambes ont été évaluées par l'échelle de Borg. Le symptôme limitant à l'exercice pouvait être la dyspnée, la fatigue des jambes ou les deux. Les patients ayant arrêté l'épreuve d'endurance en raison de fatigue des jambes ou pour une combinaison de fatigue des jambes et dyspnée, ont démontré une plus faible amélioration du temps d'endurance suite au bronchodilatateur que les patients cessant l'exercice en raison de dyspnée. La perception subjective et les mesures objectives de fatigue étaient corrélées, les patients qui ont arrêté l'épreuve en raison de fatigue des jambes ayant démontré une plus grande diminution de la force du quadriceps que les patients ayant arrêté pour dyspnée. En conclusion, la détermination du symptôme limitant à l'exercice lors d'une épreuve d'endurance est utile afin de prédire l'amélioration du temps d'endurance après bronchodilatation chez les MPOC.

\section{1} POLYSOMNOGRAPHIC CHARACTERIZATION OF MOUTH
LEAK EVENTS IN PATIENTS TREATED WITH NASAL
CONTINUOUS POSITIVE AIRWAY PRESSURE

A Garcia-Asensi ${ }^{1}$, MA Baltzan ${ }^{2,3}$, J Sully ${ }^{2}$, G Tanzimat ${ }^{1}$, I Kassissia ${ }^{1}$, N Wolkove 2,3

${ }^{1}$ OSR Medical Inc; ${ }^{2}$ Mount Sinai Hospital Centre; ${ }^{3}$ McGill University, Montreal, Quebec

BACKGROUND: Adaptation and compliance with continuous positive airway pressure (nCPAP) is often difficult, leading to inadequate treatment of obstructive sleep apnea (OSA). Mouth breathing has been described in OSA and during titration with nCPAP. It has been associated with reduced nCPAP compliance.

PURPOSE: We sought to characterize mouth breathing with attention to signal quality, event definition and associated polysomnographic events. METHODS: Eight patients with OSA and nCPAP (range 7 to $15 \mathrm{~cm} \mathrm{H}_{2} \mathrm{O}$ ) were studied with custom polysomnography. Tidal volume was measured with a pneumotachometer. Oral breath signal was generated with a peri-oral pressure transducer as well as a polyvinylidene fluoride (PVDF) film airflow sensor. Mouth breathing during calibration and in sleep shows both a relatively fast frequency 'puffing' waveform and a slow waveform in phase with tidal breathing. Scoring rules were developed. Fast events are defined as those with definite deflections with a frequency of $1 \mathrm{~Hz}$ or more. Slow mouth leaks were defined as lower frequency events of less than $1 \mathrm{~Hz}$ with concomitant increase of the nCPAP leak signal of at least 3 and at least 4 liters/min.

RESULTS: The fast 'puffing' appeared during stable REM and NREM sleep and with cortical arousals from sleep. Slow events occurred more frequently and were associated with stable sleep, as well as persistent hypopneas in sleep despite nCPAP. Some mouth leak events immediately preceded cortical arousals suggesting a causal relationship. The PVDF sensor demonstrated better signal sensitivity and reliability. Mouth leak events are observed during stable sleep and arousals from sleep, and may be a source of sleep disruption in patients treated with nCPAP.

Supported by OSR Medical Inc 
22

\section{APNET - PRELIMINARY REPORT OF A TELEMEDICINE PROJECT IN SLEEP APNEA}

\section{Lafond, F Pelland, T Morin, C Brochu}

\section{Hôpital du Sacré-Cœur de Montréal, Montréal, Québec}

A telemedicine project in sleep apnea has been set up between a rural area (Mont-Laurier) and the Sacré-Coeur Hospital in Montreal $(250 \mathrm{~km}$ apart). The project started in January 2005 under a collaboration between the FRSQ (Fonds de Recherche en Santé du Québec) respiratory health network and APNAIR sleep care (Biron Medical Laboratory).

Until October 2006, 26 family doctors sent 116 requests for 'distant consultation' by filling a form on the APNET website. Following these requests, 84 patients had a simplify home polysomnography (without EEG) performed with 'Remmers' devices. Each record sent to a remote computer server was examined and manually scored by a technician specialized in sleep medicine. Data on patients and their sleep studies were taking into account by the pneumologist before interpretation and suggestions. For 18 of the studied patients, no more investigation was recommended. For 23 of the studied patients, an in-lab polysomnography with EEG has been recommended. For 43 of the studied patients, a trial of nocturnal CPAP treatment has been proposed. Twenty-two patients completed a four-week trial of CPAP at home with the 'Autoset' machine from Resmed. During the first two weeks of the trial the machine was set up on the auto-CPAP mode, whereas the last two weeks of the trial was done with a fixed pressure mode. Every two weeks during the trial, the data on the CPAP machine was collected and sent to the server. The level of fixed pressure was assessed by the pneumologist according to the data analysis of the first two weeks on auto-CPAP. At the end of the four-week trial, a final treatment suggestion was sent to the family doctor (including specifications on pressure level to apply and mask to be used). Fifty percent of the concerned patients are now owning a CPAP machine and are using it regularly with much satisfaction.

\section{3}

\section{PROGESTERONE REDUCES APNEAS, INCREASES HYPOXIC VENTILATORY RESPONSE AND PROTECTS AGAINST PHARMACOLOGICAL INDUCTION OF PERIODIC BREATHING IN NEWBORN RATS: IMPLICATION OF D2 DOPAMINE RECEPTORS AND PERIPHERAL CHEMORECEPTORS}

R Lefter, V Joseph

Department of Pediatrics, Laval University, Québec

Progesterone $(\mathrm{P})$ reduces the occurrence of apneas in adult rats. Preterm birth produces threatening respiratory instabilities (apneas) and chronic deprivation from placental-derived P. Our hypothesis is that $\mathrm{P}$ enhances hypoxic ventilatory response (HVR) and reduces the occurrence of apneas in newborn male rats acting on dopaminergic transmission of peripheral chemoreceptors.

We studied 10-day-old rats chronically exposed to P or vehicle (Veh) that received domperidone (peripheral D2 dopamine receptor antagonist), carmoxirole (peripheral D2 dopamine receptor agonist), or saline ip injection 1 hour before respiratory and metabolic recordings (whole body plethysmography) under normoxia and acute hypoxia $\left(10 \% \mathrm{O}_{2}\right)$. Circulating levels of $\mathrm{P}$ were enhanced in pups exposed to P. Baseline respiratory and metabolic values were similar in Veh and P pups. P enhanced HVR in rat pups and reduced spontaneous apneas in normoxia and post-sigh apneas in hypoxia. Following domperidone injection, minute ventilation increased in Veh pups and the number of spontaneous apneas decreased. Following carmoxirole injection, the number of spontaneous apneas increased in Veh pups and ventilation became periodic with constant alternation of hyperand hypoventilation. These responses were not observed in P pups.

These data show that $\mathrm{P}$ is a potent stimulant of HVR in newborn rats and reduces the occurrence of apneas by reducing the dopaminergic inhibition of peripheral chemoreceptors. Furthermore, P protects against periodic breathing induced by a dopaminergic agonist presumably acting on peripheral chemoreceptors.

Supported by Sick Kids Foundation, FRSQ and IRSC
24 EVALUATION OF SLEEP LATENCY IN PATIENTS WITH
OBSTRUCTIVE SLEEP APNEA SYNDROME (OSAS)

G Rondeau, V Jobin, P Mayer, F Bellemare

Sleep Disorders Laboratory, Centre Hospitalier de l'Université de Montréal (CHUM)-Hôtel-Dieu, Montreal, Quebec

BACKGROUND: The Maintenance of Wakefulness Test (MWT) is widely used to assess excessive daytime somnolence in patients with OSAS. This technically complex test requires EEG recordings, is time consuming and expensive. A simpler behavioral maintenance of wakefulness test (OSLER test) has been recently introduced as an alternative. According to available studies, these two tests can objectively quantify daytime sleepiness with comparable results of sleep latencies. Even though the OSLER test seems reliable, its clinical use has not been widely studied in treated patients with OSAS.

METHODS: The results obtained with the OSLER test were compared to the MWT, both tests being administered simultaneously, with $4 \times 40 \mathrm{~min}$ sleep resistance challenges performed throughout the day (total 44 trials) in 11 consecutive subjects with sleep apnea, 9 of whom were treated with CPAP. All were referred for evaluation of daytime vigilance fluctuation.

RESULTS: The mean sleep latency in the 4 consecutive trials was $27.9 \pm 15.0 \mathrm{~min}$ for the MWT and $21.3 \pm 16.4 \mathrm{~min}$ for the OSLER test $(\mathrm{p}=0.001)$. Compared to the MWT, sleep latency measured by the OSLER test was shorter in 21 of 44 trials, longer in 4 and alike in 19; these two distributions being significantly different $(\mathrm{p}=0.0002)$. When using a mean sleep latency of $26 \mathrm{~min}$ for the 4 trials as the diagnostic threshold for MWT, OSLER test's sensitivity was $100 \%$ and specificity $57 \%$.

CONCLUSIONS: A normal OSLER test result is appropriate to rule out significant somnolence. However, considering the low specificity, caution must be exercised when interpreting an abnormal OSLER test result in the evaluation of daytime sleepiness in patients with OSAS. More studies are needed to assess the clinical significance of fluctuations in vigilance, without electroencephalographic-identified sleep, that the OSLER test has detected.

\section{5}

ABNORMAL CONTRACTILE FUNCTION AND CALCIUM HOMEOSTASIS IN CFTR-DEFICIENT SKELETAL MUSCLE H Balghi ${ }^{1}$, M Divangahi ${ }^{1}$, R Robert ${ }^{2}$, G Danialou ${ }^{1}$, D Gvozdic ${ }^{1}$, JW Hanrahan ${ }^{2}$, BJ Petrof ${ }^{1}$

${ }^{1}$ Meakins-Christie Laboratories, Respiratory Division; ${ }^{2}$ Department of Physiology, McGill University, Montreal, Quebec

Cystic fibrosis (CF) is caused by mutations in the cystic fibrosis transmembrane conductance regulator (CFTR). Many CF patients show reduced strength or endurance of respiratory muscles. We hypothesized that CFTR itself could play an important role in skeletal muscle physiology. CFTR mRNA expression was demonstrated in murine and human skeletal muscle cells by RT-PCR. Immunostaining of cultured muscle cells and skeletal muscle fiber cross-sections confirmed the presence of CFTR protein. Confocal microscopy showed co-localization of CFTR with both plasma membrane- and sarcoplasmic reticulum-associated proteins. To determine whether skeletal muscle CFTR is functional, the contractile responses to depolarization induced by $60 \mathrm{mM} \mathrm{KCl}$ were compared in diaphragm muscle strips obtained from CFTR knockout (cftr-l-) and normal wild-type $(\mathrm{ctrr}+/+)$ mice. There were major differences in the responses of $\mathrm{cftr}-/-$ and $\mathrm{ctr}+/+$ mice, particularly with respect to the relaxation phase, which was greatly prolonged in cftr- $/-$ muscle. Because contractile responses are linked to intracellular $\mathrm{Ca} 2+$, the latter was measured in primary myotubes from cftr- $/-$ and $\mathrm{cftr}+/+$ mice using the ratiometric $\mathrm{Ca} 2+$ probe fura- 2 . Increases in intracellular Ca2+ induced by $60 \mathrm{mM} \mathrm{KCl}$ solution were significantly greater in $\mathrm{cftr}-/-$ than in $\mathrm{cftr}+/+$ myotubes. This abnormal $\mathrm{Ca} 2+$ response in the $\mathrm{cftr}-/$ - group was reproduced when $\mathrm{cftr}+/+$ myotubes were treated with CFTRinh-172, while the inhibitor had no effect in cftr-/- myotubes.

CONCLUSIONS: (i) CFTR is normally expressed in skeletal muscle; and (ii) Lack of normal CFTR function in skeletal muscle leads to abnormal contractile responses and intracellular $\mathrm{Ca} 2+$ fluxes.

Supported by CIHR, CCFF 
26

\section{REGULATION OF MATRIX METALLOPROTEINASE-9 RELEASE FROM 5-OXO-ETE STIMULATED HUMAN EOSINOPHILS}

A Langlois, C Ferland, N Pagé, M Laviolette

Unité de recherche en pneumologie, Centre de recherche de I'Hôpital Laval, Université Laval, Quebec

RATIONALE: Migration of blood eosinophils through endothelium and tissue extracellular matrix requires proteolysis. We previously showed that 5-oxo-6,8,11,14-eicosatetraenoic acid (5-oxo-ETE), a potent eosinophil chemotactic factor, activates matrix metalloproteinase (MMP)-9 secretion in vitro. However, 5-oxo-ETE-induced signalling pathways implicated in migration and proteases activation have not been reported. Of the many signalling pathways, protein kinase $\mathrm{C}(\mathrm{PKC})$ and mitogen-activated protein kinase/extracellular signal-regulated kinase (MAPK/ERK) are involved in MMP-9 release in many cell types.

HYPOTHESIS: We postulated that selective inhibition of theses kinases block eosinophil migration by decreasing MMP-9 secretion and activity.

METHODS: Purified peripheral blood eosinophils from asthmatic subjects were pre-incubated with or without different selective PKC inhibitors (isoforms alpha/beta: Ro-31-8425, isoform delta: Rottelin or PKC zeta blocking peptide), ERK inhibitor (PD98054) or p38 MAPK inhibitor (SB203580), for $30 \mathrm{~min}$ at $37^{\circ} \mathrm{C}$, followed by addition of 5-oxo-ETE. Migration assays and rapid MMP-9 release (within an hour; evaluated by zymography) were assessed.

RESULTS AND CONCLUSION: All of these inhibitors decreased 5-oxoETE-induced eosinophil migration through Matrigel. However, only PKC delta and ERK signalling pathways reduced rapid release of MMP-9, suggesting that the other kinases studied could act on MMP-9 synthesis, protease generation, adherence or cell motility, also involved in 5-oxo-ETE-induced migration.

\section{7}

\section{STRUCTURAL CHANGES AND AIRWAY REMODELLING IN OCCUPATIONAL ASTHMA 10 YEARS AND MORE AFTER CESSATION OF EXPOSURE TO THE CAUSATIVE AGENT}

Y Sumi $^{1}$, JS Foley ${ }^{1}$, J L'Archeveque ${ }^{2}$, S Daigle ${ }^{2}$, S Létuvé ${ }^{1}$, JL Malo ${ }^{2}$, Q Hamid ${ }^{1}$

${ }^{1}$ Meakins-Christie Laboratories, McGill University; ${ }^{2}$ Department of Chest Medicine, Sacré-Coeur Hospital, Montreal, Quebec

RATIONALE: Occupational asthma (OA) can cause alterations of airways with inflammation and airway remodelling after cessation of exposure, but the long-term pathological outcomes have not been examined. HYPOTHESIS: We aimed to investigate if pathological changes consistent with airway remodelling were present in the airways of subjects who had clinically and functionally recovered from asthma 10 years or more after cessation of exposure to an agent that had caused OA.

SUBJECTS AND METHODS: Ten subjects in the 'cured' group underwent bronchoscopy with bronchoalveolar lavage and bronchial biopsies. Comparisons were made with bronchial biopsies from control subjects. Airway remodelling was estimated by epithelial detachment, epithelial metaplasia, areas occupied by collagen, distance between epithelium and ASM, mucus gland area and airway smooth muscle (ASM) area on Hematoxylin and Eosin staining or van Gieson staining. The numbers of TGF- $\beta 1$ and ECP positive cells were evaluated by specific immunostaining.

RESULTS: There was a statistically significant increase in the number of TGF- $\beta 1$ positive cells in subjects with OA compared to controls while the distance between the epithelium and ASM was decreased in OA subjects. The difference in epithelial metaplasia, ASM mass, mucus gland numbers, subepithelial fibrosis, collagen deposition and eosinophilia in OA compared to controls did not reach statistical significance.

CONCLUSION: Some aspects of airway remodelling and inflammation persist in OA 10 years and more after cessation of exposure even in the absence of clinical and functional abnormalities.

Funded by the Canadian Institutes of Health Research to the Asthma in the Workplace Center (CDA66154)
28

ACTIVATION DE LA VOIE UBIQUITINE-PROTÉASOME

CHEZ DES PATIENTS ATTEINTS D'UNE MALADIE PULMONAIRE OBSTRUCTIVE CHRONIQUE (MPOC) EN ÉTAT STABLE ET PRÉSENTANT DE L'ATROPHIE MUSCULAIRE

$\underline{\text { M Doucet }}{ }^{1}$, AP Russell2 ${ }^{2}$, R Debigaré1, DR Joanisse ${ }^{3}$, B Léger²,

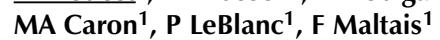

${ }^{1}$ Centre de recherche de l'Hôpital Laval, Institut universitaire de cardiologie et de pneumologie de l'Université Laval, Québec; ${ }^{2}$ Clinique Romande de Réadaptation SUVA Care, Sion, Suisse; ${ }^{3}$ Division de Kinésiologie, Université Laval, Québec

La cause de l'atrophie musculaire dans la MPOC est inconnue. Cependant, des études récentes chez l'homme démontrent que l'activation de la voie ubiquitine-protéasome (surexpression de Atrogin-1 et MuRF1), agirait directement sur la masse maigre en stimulant la dégradation protéique. De plus, la voie de signalisation IGF-I via AKT/FOXOs $(1,3)$ serait principalement impliquée dans cette activation.

BUT: Mesurer l'expression en protéines de $\mathrm{AKT}$ et $\operatorname{FOXOs}(1,3)$ ainsi que l'expression de l'ARNm de Atrogin-1 et MuRF1 dans le vastus lateralis (VL) de 12 patients MPOC en état stable et présentant une atrophie musculaire (VEMS: $31 \pm 10 \%$ prédite, moy $\pm \mathrm{SD}$ ) comparer à 10 sujets témoins $(\mathrm{T})$.

MÉTHODOLOGIES: Une mesure de la surface de masse musculaire de la cuisse effectuée par tomodensitométrie (MTCSA) et une biopsie à l'aiguille du VL ont été faites. Le contenu en protéines et l'expression de l'ARNm ont été mesurés par Western blot et par PCR quantitatif respectivement (les données sont exprimées en unités arbitraires, moy \pm SEM).

RÉSULTATS: Lorsqu'on compare le groupe MPOC au groupe T le MTCSA $\left(73 \pm 11 \mathrm{~cm}^{2}\right.$ vs $\left.99 \pm 14 \mathrm{~cm}^{2}, \mathrm{p}<0,001\right)$ est diminué. Une augmentation de l'expression de l'ARNm de Atrogin-1 $(0,43 \pm 0,09$ vs $0,18 \pm 0,04$, $\mathrm{p}<0,05)$ et MuRF1 $(4,55 \pm 0,97$ vs $0,88 \pm 0,27, \mathrm{p}<0,01)$ est présente chez les sujets MPOC comparé au groupe T. De plus, une augmentation de l'expression en protéines de FOXO1 $(1,27 \pm 0,19$ vs $0,75 \pm 0,08, p<0,05)$ ainsi que le ratio d'activité de AKT $(2,06 \pm 0,77$ vs $0,42 \pm 0,08, p<0,01)$ est observé dans le groupe MPOC en comparaison au groupe T. Le contenu en protéine de $\mathrm{FOXO} 3$ est semblable entre les deux groupes.

CONCLUSION: Une augmentation de l'expression de l'ARNm de Atrogin-1, MuRF1 et de FOXO1 a été observée chez des patients MPOC présentant de l'atrophie musculaire. L'expression de Atrogin-1 et MuRF1 semble être régulée par FOXO1 mais n'impliquerait pas en amont la voie de signalisation IGF-I/AKT.

\section{9}

AUGMENTATION DE L'EXPRESSION DES RÉCEPTEURS DU «TNF-RELATED APOPTOSIS-INDUCING LIGAND » (TRAIL) ET DU FACTEURS PRO-APOPTOTIQUE BAX CHEZ LES SUJETS EMPHYSÉMATEUX

\section{Morissette, J Parent, J Milot}

Hôpital Laval, Québec

L'emphysème se caractérise par la présence d'inflammation et d'une destruction du parenchyme pulmonaire. Il a été démontré que l'apoptose alvéolaire est augmentée dans l'emphysème mais les voies apoptotiques impliquées demeurent inconnues. Notre hypothèse est que les voies apoptotiques du « TNF-related apoptosis-inducing ligand » (TRAIL) et de Bax sont modulées dans l'emphysème. TRAIL peut induire l'apoptose cellulaire de façon " caspases dépendante » et peut aussi activer le facteur de transcription NF-kB. Bax est un facteur pro-apoptotique qui agit au niveau de la mitochondrie et dont la transcription peut être augmentée par les dommages à l'ADN.

MÉTHODE : Des extraits protéiques de parenchyme pulmonaire provenant de sujets normaux fumeurs (NF) et non-fumeurs (NNF) et emphysémateux fumeurs (EF) et ex-fumeurs (ExF) ont été analysés par immunobuvardage pour les 4 récepteurs de TRAIL ainsi que pour Bax. RÉSULTATS : Nous avons observé que trois des quatre récepteurs de TRAIL, deux récepteurs pro-apoptotiques (TRAIL-R1 et R2) et un récepteur anti-apoptotique (TRAIL-R3), sont augmentés significativement dans l'emphysème. Alors que Bax n'est pas détecté chez les NNF, il est 
induit chez les NF et les ExF avec un effet synergique important chez les EF. CONCLUSION : Les voies apoptotiques de TRAIL et de Bax sont modulées dans l'emphysème. Les variations de Bax démontreraient une activation de p53 en réponse au stress du tabagisme et/ou de l'inflammation. Pour ce qui est des récepteurs de TRAIL, une participation conjointe de p53 et de facteurs inflammatoires pourrait expliquer l'augmentation de l'expression des récepteurs chez les sujets EF et leur maintient chez les ExF.

\section{0}

\section{ACTIVATION OF NEUTROPHILS BY INTERLEUKIN-4, IN AN EQUINE MODEL OF ASTHMA}

A Lavoie-Lamoureux ${ }^{1}$, C Cesarini ${ }^{1}$, G Beauchamp ${ }^{1}$, JG Martin ${ }^{2}$, JP Lavoie ${ }^{1}$

${ }^{1}$ Clinical Sciences, University of Montreal, Saint-Hyacinthe; ${ }^{2}$ Department of Physiology, Meakins-Christie Laboratories, McGill University, Montreal, Quebec

RATIONALE: Neutrophilic airway inflammation is a common feature of asthmatic exacerbations. The aim of this study was to investigate the effect of Interleukin (IL)-4, a Th2-type cytokine, on neutrophils, in the context of allergic pulmonary diseases.

METHODS: Heaves-affected horses were used during this study as a natural model of allergic asthma. To assess the biological activity of recombinant equine (re)IL-4 on equine neutrophils, dose (4, 40 or $400 \mathrm{LabU} / \mathrm{mL}$ ) and time (5-18h) -titration studies were performed using purified peripheral blood neutrophils from healthy horses. Inverted microscopic observation of neutrophils, chemotactic activity of the culture supernatants (Boyden chamber) as well as gene expression analysis (real-time PCR) was performed. Secondly, we submitted heaves-affected horses and control horses to an antigenic challenge with mouldy hay for 30 days. Respiratory mechanics were performed on horses before and after challenge. At each time point, we compared the gene expression of peripheral blood neutrophils from heaves-affected and control horses, following incubation with reIL-4 (5h).

RESULTS: ReIL-4 directly activated neutrophils by inducing morphologic changes, regulation of gene transcription (IL-8, IL-1 $\beta$, TNF- $\alpha$, TLR4, IL-4R $\alpha$ ) and by increasing the chemotactic activity of the culture supernatants toward other neutrophils. Neutrophils from the two groups of horses responded similarly to reIL-4. Challenge with hay further augmented the positive effect of relL- 4 on IL- 8 transcription by neutrophils.

CONCLUSION: These results suggest that IL-4 may be involved in the development of pulmonary neutrophilia in affected horses, particularly by positively regulating the expression of IL- 8 by neutrophils. This phenomenon could be responsible for the persistent recruitment and activation of neutrophils in the airways of diseased animals.

This study was supported by NSERC of Canada and GREMEQ

\section{1}

\section{DEVELOPMENT OF A CHIMERIC FC(EPSILON)RI ALPHA- CHAIN RECEPTOR FOR THE DETERMINATION OF SENSITIZATION TO OCCUPATIONAL AGENTS}

\section{B St-lacques, M Welman, S Favret, K Maghni}

Research Center, Sacré-Cœur Hospital of Montreal, Laboratory of Asthma Neuroimmunology, Université de Montréal, Montreal, Quebec

There are more than 300 occupational agents to which some workers are susceptible to develop an IgE sensitization. Rat basophilic RBL-2H3 cells tranfected with the human FceRI $\alpha$-chain are able to bind human $\operatorname{IgE}$ (hIgE), and constitute a cell degranulation-based assay to detect IgE sensitization in human sera. However, it was found that only about $25 \%$ of the human $\alpha$-chains assemble themselves with rat $\beta$-chains in this cell line. As a consequence, this cell line has a low hIgE dependent degranulation potential. AIM: To develop a chimeric FceRI $\alpha$-chain to be transfected in RBL-2H3 cells (RBL-cFc\&RI- $\alpha^{+}$) that is composed of a) part of the human Fc\&RI $\alpha$-chain sequence responsible for hIgE binding, and b) part of the rat $\alpha$-chain sequence for improving its assembling with the rat $\beta$ and $\gamma$-chains. Furthermore, a mutation will be introduced in the IgE binding domain of the chimeric Fc\&RI $\alpha$-chain to increase its affinity to hIgE.
METHODS AND RESULTS: cDNA regions coding for the extracellular part of the human $\alpha$-chain, and the transmembrane and intracellular parts of the rat $\alpha$-chain were amplified by PCR. cDNA regions were then ligated together and cloned into the pTarge T vector. Positive clones were screened by sequencing. One clone was selected, and the mutagenesis was performed. This mutant will be transfected in RBL-2H3 cells. Stable transfectants will be selected by growing cells with G-418, and further selected for the level of expression and functionality of the chimeric $\alpha$-chain. CONCLUSION: The RBL-cFceRI- $\alpha^{+}$cell line will provide a powerful tool to quantify IgE-dependent immunization to occupational agents. Supported by the Asthma and Workplace Center (CIHR)

\section{2}

\section{OCCUPATIONAL RHINOBRONCHIAL DISEASE: JOINT ASSESSMENT OF OCCUPATIONAL ASTHMA AND OCCUPATIONAL RHINITIS DURING SPECIFIC INHALATION CHALLENGE}

R Castano, JL Malo, H Ghezzo, D Gautrin

Centre asthme et travail, Hôpital du Sacré-Coeur de Montréal, Centre de Recherche/Pneumologie, Montreal, Quebec

BACKGROUND: The links between asthma and rhinitis are nowadays referred to as the united airways concept. Current evidence shows that this model is applicable to occupational rhinitis (OR) and occupational asthma $(\mathrm{OA})$. Differing from OA, OR seems to be under-diagnosed. If rhinitis and asthma are manifestations of a same disease, both may be objectively diagnosed following a similar and parallel approach.

PURPOSE: The objective of this study was to evaluate the utility of acoustic rhinometry (AR) to diagnose OR by assessing changes in nasal patency during specific inhalation challenge (SIC) and to explore the relationship between $O R$ and OA.

METHODS: Forty-nine workers with a history of work-related asthma symptoms underwent SIC for confirmation of OA. Altogether 62 SIC with either high- or low-molecular weight agents were conducted. They were administered a questionnaire on nasal symptoms and had an objective parallel monitoring of nasal patency by AR during the SIC.

RESULTS: Symptoms of rhinitis at work were reported by $91 \%$ of subjects. Work-related rhinitis symptoms appeared before or at the same time ( $80 \%$ of subjects) but not after ( $18 \%$ of subjects) work-related asthma symptoms. Based on the change in nasal patency, 28/62 SIC were categorized as positive for OR; 18/62 were categorized as positive for OA; and $9 / 62$ were categorized as positive for both OR and OA. Among cases with both diagnosis the association was observed mostly in cases due to high molecular weight $(n=8)$ than low-molecular weight agents $(n=1)$.

CONCLUSIONS: These results provide evidence on the link between $\mathrm{OR}$ and $\mathrm{OA}$ supporting the concept of an occupational rhinobronchial disease. AR is a useful and objective investigational tool to diagnose OR during SIC. OR was diagnosed more frequently than OA during SIC. A joint approach for the diagnosis of OR and OA by SIC can be recommended.

\section{3}

\section{ÉVALUATION DE LA RÉPONSE CLINIQUE SUITE À UNE PROVOCATION NASALE MULTIPLE CHEZ DES SUJETS RHINITIQUES AVEC OU SANS}

MC Rousseau, ME Boulay, LP Boulet

Centre de recherche de l'Hôpital Laval, Institut universitaire de cardiologie et de pneumologie de l'Université Laval, Québec

INTRODUCTION: La provocation nasale (PN) allergénique est une méthode permettant d'étudier les mécanismes pathophysiologiques de la rhinite allergique. Nous croyons qu'une PN multiple serait plus représentative de la réalité qu'une $\mathrm{PN}$ unique.

BUT: Déterminer l'effet d'une PN multiple durant 4 jours consécutifs sur les symptômes de rhinite et les débits respiratoires chez des sujets rhinitiques avec ou sans asthme.

SUJETS: Dix-sept sujets avec rhinite allergique : 9 avec asthme et 8 sans asthme.

MÉTHODES: Une PN contrôle avec une solution saline a d'abord été effectuée, suivie d'une PN multiple, sur 4 jours consécutifs. À chaque 
provocation, une dilution déterminée d'allergène était vaporisée dans les narines du patient jusqu'à l'obtention d'une réponse positive. Les patients notaient leurs symptômes d'après une échelle Likert et mesuraient leurs débits respiratoires, permettant d'obtenir l'indice de congestion nasal (ICN), jusqu'à 7 h post-provocation.

RÉSULTATS: En comparaison avec le jour contrôle, il y avait une augmentation significative de l'ICN et du score de symptômes à 10 min postprovocation après chacune des $\mathrm{PN}$ dans les deux groupes $(\mathrm{p}<0.05)$. Il n'y avait pas de différences significatives des scores de symptômes ou de l'ICN entre les différentes journées de provocation, malgré une exposition à des doses similaires d'allergène $(p>0.05)$. L'ICN et les scores de symptômes étaient comparables entre les 2 groupes, excepté pour la toux, qui était plus importante chez les rhinitiques sans asthme $(\mathrm{p}<0.05)$.

CONCLUSION: La PN allergénique multiple semble être une méthode utile pour faire l'étude des mécanismes de rhinite allergique.

\section{4}

\section{COMMENT PARVENIR À UN CONTRÔLE OPTIMALE DE L'ASTHME? L'INFLUENCE DU SENTIMENT D'AUTO- EFFICACITÉ}

\section{A Bouchard ${ }^{1,2}$, H Favreau ${ }^{1,2}$, M Piccioni ${ }^{2,3}$, M Labreque ${ }^{2}$, SL Bacon $^{2,3}$, KL Lavoie $^{1,2}$}

1'Département de psychologie, Université du Québec à Montréal (UQAM); ${ }^{2}$ Centre de recherche, Hôpital du Sacré-Coeur de Montréal; ${ }^{3}$ Exercise Science, Concordia University, Montreal, Quebec

INTRODUCTION: Plus de 50\% des asthmatiques contrôlent leur maladie de façon inadéquate, impliquant des enjeux médicaux importants. Divers facteurs, psychologiques et comportementaux, sont associés au contrôle de l'asthme et seraient influencés par le sentiment d'auto-efficacité des patients face à la maladie.

OBJECTIF: Évaluer l'association entre le sentiment d'auto-efficacité lié à l'asthme, le niveau de contrôle de l'asthme et la qualité de vie chez les asthmatiques.

MÉTHODE: Un total de 550 patients avec un diagnostic d'asthme ont été vues lors de leur visite à la clinique d'asthme de l'hôpital du SacréCœur de Montréal. Les patients ont complété une entrevue sociodémographique, des questionnaires (auto-efficacité liée à l'asthme (ASES), contrôle de l'asthme (ACQ), qualité de vie reliée à l'asthme (AQLQ)) et ont réalisé une spirométrie.

ANALYSES: Une série de test-t et chi-carrés ont été faite pour évaluer l'association entre l'ASES et les variables sociodémographiques, médicales et celles liées à l'asthme. Deux modèles généraux linéaires ont été utilisés afin d'évaluer l'association entre les scores à l'ASES et ceux à l'ACQ et à l'AQLQ en contrôlant pour l'age, le sexe, et la sévérité de l'asthme.

RÉSULTATS: Les résultats montrent une association négative entre les scores de l'ASES et ceux de l'ACQ $(t=-11.40, p<.0001)$ et positive avec ceux de l'AQLQ $(\mathrm{t}=17.73, \mathrm{p}<.0001)$. De plus, à l'exception du VEMS (\% de la valeur prédite), une association négative entre les scores de l'ASES et tout les items de l'ACQ $(t=-6.28$ à $-12.02, p<.0001)$ et une association positive entre l'AESE et tous les sous-échelles de l'AQLQ $(\mathrm{t}=13.94$ à $16.67, \mathrm{p}<.0001)$ ont été observées. Tous les résultats étaient indépendants de l'âge, du sexe et de la sévérité de l'asthme.

CONCLUSION: Un faible sentiment d'auto-efficacité serait relié à certains indices d'un mauvais contrôle de l'asthme et à une moins bonne qualité de vie chez les asthmatiques. Des études visant l'augmentation du sentiment d'auto-efficacité sur le niveau de contrôle de l'asthme sont nécessaires.

There are no conflicts of interest

\section{5} DIMINUTION DE LA TAILLE DES TÉLOMÈRES ET
AUGMENTATION DE LA SÉNESCENCE DES FIBROBLASTES
ISOLÉS DE BRONCHES DE SUJETS ASTHMATIQUES

LDubé, N Morin, S Plante, J Chakir

Université de Sherbrooke et Centre de recherche de l'Hôpital

Laval, Québec

L'asthme est associé à la fibrose sous-épithéliale bronchique. Les fibroblastes bronchiques ont un rôle important dans le développement de cette fibrose. Le nombre de fibroblastes est augmenté dans le sous-épithélium des bronches d'asthmatiques ce qui suggère que ces cellules se sont divisées sous l'action de médiateurs inflammatoires provenant de la réaction allergique. La plupart des cellules humaines ont une limite de division cellulaire au-delà de laquelle elles atteignent la sénescence réplicative. La sénescence réplicative est associée à la diminution de la taille des télomères. En sénescence réplicative, les cellules cessent de proliférer, mais restent métaboliquement actives et peuvent donc contribuer à la physiopathologie de certaines maladies. Nous émettons l'hypothèse que l'hyperprolifération des fibroblastes bronchiques dans l'asthme aurait comme conséquence une diminution prématuré de la taille de leurs télomères. Dans cette étude, nous comparons la taille des télomères de fibroblastes bronchiques isolés de sujets asthmatiques $(n=6)$ et de sujets normaux $(n=5)$. Les résultats montrent une diminution significative de la taille moyenne des télomère $(\mathrm{p}<0.05)$ et ce par deux techniques de mesure indépendante (Southern blot et Q-FISH). De plus, nous avons démontré une relation significative entre la taille des télomères et l'hyperréactivité bronchique des sujets ( $r=0.75$ et $r=0.82$ par Southern et Q-FISH respectivement). Finalement, nous avons démontré que le pourcentage de fibroblastes exprimant le SA- $\beta$-gal, un marqueur de sénescence, est significativement plus élevé dans le groupe de sujets asthmatiques $(\mathrm{p}<0,05)$. Ces résultats suggèrent que les fibroblastes des bronches d'asthmatique se sont divisés in vivo plus que ceux des sujets normaux. Le rôle de la diminution de la taille des télomères et de l'augmentation du nombre de cellules sénescentes dans l'asthme est encore inconnu, mais il est possible que l'âge réplicatif contribuent à la physiopathologie de l'asthme.

\section{6}

LE PLAN PROVINCIAL EN ASTHME (PPA), DESCRIPTION DE L'ÉTUDE ET RÉSULTATS SUR LA VALIDATION D'UN PLAN D'ACTION-PRESCRIPTION (PAP) SIMPLIFIÉ

PM Renzi, F Borduas, S Goulet, M Labelle, E Dorval, M Rouleau, RL Thivierge

Formation professionnelle continue, Départements de Médecine, Universités de Montréal et Laval, Québec

Nous avons récemment publié qu'une étampe résumant les critères de maîtrise et de traitement du consensus canadien en asthme augmentait les connaissances de médecins omnipraticiens et diminuait les visites à l'urgence et hospitalisations de leurs patients. Cette étampe avait moins d'effets sur les connaissances thérapeutiques et l'emploi de l'étampe ne diminuait pas les visites à l'urgence et hospitalisations de patients asthmatiques qui n'avaient pas été suivis pour asthme par le même médecin au cours de l'année antérieure. Le but du PPA est d'évaluer si l'addition d'un PAP qui sert à la fois de prescription et de plan d'action, à l'étampe, aura plus d'effets sur les connaissances thérapeutiques et la morbidité de patients asthmatiques qui ne sont pas suivis régulièrement. Cent un médecins omnipraticiens participent à cette étude dans 5 régions du Québec. Ils ont été randomisés en trois groupes: contrôle (consensus par la poste seul); consensus, étampe et PAP avec instructions par la poste; et consensus, étampe et PAP enseignés à une soirée d'EMC. Deux PAP (simple $(\mathrm{S})$ et complet $(\mathrm{C})$ ) ont été concus et présentés pour validation à 20 omnipraticiens lors d'une soirée dans la région de Québec. Sept critères d'appréciation ont été cotés par les médecins. Le pourcentage en accord, très en accord fut le suivant pour $\mathrm{S}$ et $\mathrm{C}$, respectivement: utile et pertinent: 75 vs 65; facile: 95 vs 45; informations essentielles: 70 vs 90 ; présentation simple: 95 vs 30; temps requis adéquat: 95 vs 35; consignes clairs: 85 vs 70; s'intègre facilement au dossier patient: 90 vs 75. En tenant compte de ces résultats nous avons décidé de procéder avec le PAP simple. 


\section{7}

\section{CARACTÉRISATION MICROBIENNE DES BIOAÉROSOLS DES PORCHERIES DU QUÉBEC À L'AIDE D'OUTILS DE BIOLOGIE MOLÉCULAIRE: UNE NOUVELLE VISION DE CET ENVIRONNEMENT DE TRAVAIL}

B Nehmé ${ }^{1}$, V Létourneau ${ }^{1}$, RJ Forster ${ }^{2}$, A Mériaux ${ }^{1}$, M Veillette ${ }^{1}$, C Duchaine $^{1}$

${ }^{1}$ Centre de recherche en pneumologie, Hôpital Laval, Québec;

${ }^{2}$ Agriculture and Agri-Food Canada, Lethbridge, Alberta

Des études sur la santé des travailleurs, notamment dans le milieu de l'industrie porcine, ont associé l'apparition de syndromes respiratoires et d'inflammations des voies aériennes lors de l'exposition à des bioaérosols. Leur nocivité est souvent évaluée par l'abondance d'endotoxines dans l'air, niant la nocivité de contaminants mal, ou non identifiés. Les bactéries représentent une part importante du contenu des bioaérosols. Cependant leurs natures demeurent mal connues, puisque car à ce jour seules les méthodes d'identification par culture ont été utilisées. Leur caractérisation dans les bioaérosols des porcheries a été effectuée à l'aide d'outils de biologie moléculaire indépendante de leur caractère cultivable. Les résultats révèlent une très forte prévalence des bactéries anaérobies à Gram positif de la classe des Clostridia. Malgré une importante littérature scientifique, il existe uniquement des recommandations quant aux taux d'endotoxines issues des bactéries à Gram négatif, et aucune valeur limite pour la présence de peptidoglycanes issus des bactéries à Gram positif, bien que leur caractère pro-inflammatoire soit reconnu. Par ailleurs, des archaebactéries méthanogènes ont également été caractérisées pour la première fois dans un bioaérosol. Ces résultats questionnent la validité de la mesure des endotoxines comme seul marqueur de l'exposition microbienne, ainsi que l'effet que pourrait avoir ces bioaérosols sur la santé humaine.

Supported by CRSNG et IRSST. B Nehmé et V Létourneau sont boursiers du PHARE training program. C Duchaine est boursière IRSST/IRSC et FRSQ

\section{8}

\section{IDENTIFICATION DE GÈNES CANDIDATS POUR L'ASTHME PAR LA TECHNOLOGIE DES PUCES À ADN}

A Chamberland ${ }^{1,2}, \mathrm{~K}_{\text {Tremblay }}{ }^{1,2}$, MC Bernier ${ }^{1,3}$, J Chakir $^{1,3}$, M Laviolette ${ }^{1,3}$, C Laprise ${ }^{2,4}$

${ }^{1}$ Université Laval; ${ }^{2}$ Centre de médecine génique communautaire (UdeM); ${ }^{3}$ Institut universitaire de cardiologie et de pneumologie de l'Université Laval; ${ }^{4}$ Université du Québec à Chicoutimi, Québec

CONTEXTE: L'asthme (AA) et la rhinite (RA) allergique partagent une étiologie inflammatoire commune par l'intermédiaire des mêmes constituants moléculaires et cellulaires. Bien qu'une prédisposition génétique pour l'atopie soit documentée pour ces deux phénotypes, nous devons identifier les biomarqueurs spécifiques à l'un ou l'autre de ces traits complexes.

OBJECTIFS: 1) Comparer le patron de milliers de gènes de sujets témoins ( $\mathrm{Tm}$ ) (sans asthme ni allergie), RA, AA et asthmatiques non-allergiques (ANA); 2) Cibler des biomarqueurs spécifiques à l'asthme.

MÉTHODE: Des biopsies bronchiques ont été effectuées chez $4 \mathrm{Tm}$, 4 RA, 4 AA et 4 ANA. L'ARN extrait par la technique QIAGEN a servi à mesurer le niveau d'expression par puces à $\mathrm{ADN}$. La sélection des biomarqueurs candidats s'est faite parmi ceux communs à au moins trois analyses comparatives et sur la base de leur fonction biologique.

RÉSULTATS: Les 6 analyses comparatives (Tm/RA, Tm/AA, Tm/ANA, ANA/AA, RA/AA et RA/ANA) ont permis de noter des différences d'expression pour respectivement 20,19,284, 251, 40 et 9 gènes. Parmi ceux-ci, 5 sont des molécules de signalisation immunes et 5 sont des molécules inflammatoires. Un de ces candidats (CX3CR1) a été associé à l'asthme et 2 autres ont été identifiés à partir des voies biologiques de ces biomarqueurs.

PERSPECTIVES: Une étude fonctionnelle sur CX3CR1 sera réalisée à l'aide de lymphocytes $\mathrm{T}$ sanguins afin d'évaluer le taux de CX3CR1 à la surface ces cellules, d'étudier sa signalisation et ses propriétés d'adhésion en présence ou non de l'haplotype associé. L'étude de cette voie biologique permettra d'augmenter les connaissances sur les composantes inflammatoires de l'asthme.

\section{9}

LUNG DEVELOPMENT: ACTIVE ANDROGEN METABOLISM DURING THE SACCULAR STAGE IN MOUSE

E Boucher ${ }^{1,2}$, Y Tremblay 1,2,3

1'Laboratory of Ontogeny and Reproduction, CHUQ, CHUL, Faculty of Medicine; ${ }^{2}$ Centre de Recherche en Biologie de la Reproduction (CRBR), Laval University; ${ }^{3} \mathrm{Ob} / \mathrm{Gyn}$ Department, Faculty of

Medicine, Laval University, Quebec City, Quebec

BACKGROUND: Prematurity affects boys and girls in equal proportions, but boys that are born prematurely are $62 \%$ more likely to develop respiratory distress syndrome (RDS) than girls born at a similar age. Male fetuses are exposed to higher androgen levels leading to a normal delay in pulmonary development and to a predisposition to RDS. Nevertheless, androgens are necessary for branching during early lung development, where they participate in the regulation of apoptosis and cellular proliferation. PURPOSE: To asses the presence of an active androgen metabolism/catabolism during the saccular stage of lung development and the roles of active androgens during this stage.

METHODOLOGY: Messenger RNA were extracted and corresponding cDNA banks were prepared from lung taken from mice pups sacrificed before parturition (gestational day 19.5 ; parturition on this day), immediately after parturition (PNO) and 1, 2, 3 or 5 days after birth. Expression levels for 17ßHSD-2, 17ßHSD-5 and androgen receptor (AR) transcripts were then quantified by real-time PCR.

RESULTS: Transcripts for 17ßHSD-2, 17ßHSD-5 and AR were detected in saccular stage mouse lungs. However, no significant variation in level of transcripts was seen in the time period studied, nor in association with sex specificity. Transcript levels for 17 $\beta$ HSD-2 and 17ßHSD-5 suggests that an active androgen catabolism is present at the tissue level at the saccular stage of lung development in mouse.

\section{0}

\section{SENSIBILITÉ DES BRONCHIOLES HUMAINES AUX ÉİCOSANOÏDES BRONCHODILATATEURS : EET ET 20-HETE}

C Morin, M Sirois, V Échavé, MM Gomes, E Rousseau

Département de Physiologie et Biophysique, FMSS, Université de Sherbrooke, Service de Chirurgie Thoraxique et Département de Pathologie, CHUS, Sherbrooke, Quebec

Le but est de quantifier les effets fonctionnels des eïcosanoïdes de nouvelle génération sur la réactivité mécanique des bronchioles humaines en culture. Ces substances jouent un rôle important dans la modulation des réponses immuno-inflammatoires. Des mesures pharmaco-mécaniques couplées à des enregistrements électrophysiologiques et à des analyses par Western blot ont permis une évaluation quantitative des bronchioles disséquées à partir de 32 résections pulmonaires. Les mesures de tension démontrent que le 14,15-EET et le 20-HETE (deux dérivés de l'acide arachidonique via les Cytochromes P-450) induisent des relaxations concentration-dépendantes des tissus humain pré-contractées à la MCh et à l'AA. Ces eicosanoides ont des effets hyperpolarisant sur la membrane des cellules des MLVR. Les réponses relaxantes induites par le 14,15-EET sont également liées à une diminution de la sensibilité des myofilaments au $\mathrm{Ca}^{2+}$, tel que démontré par des variations de pCa sur des explants perméabilisés à la $\beta$-escine. Le 14,15-EET inhibe également les réponses contractiles induites par le PDBu, un activateur de la PKC, tout en diminuant le niveau de phosphorylation de la CPI-17. De plus, $0.1 \mu \mathrm{M}$ de 14,15 -EET diminue la réactivité et la sensibilité au $\mathrm{Ca}^{2+}$ des tissus traités au TNF $\alpha$. Ces résultats indiquent que le 14,15-EET et le 20-HETE hyperpolarisent et relaxent les cellules des muscles lisses bronchiques. Le 14,15-EET interfère aussi avec le niveau de phosphorylation de protéines régulatrices (CPI-17) ce qui résulte en une diminution du tonus pour une $\left[\mathrm{Ca}^{2+}\right]$ donnée. De plus, cet eïcosanoïde a un effet anti-inflammatoire marqué sur des bronches rendues hyper-réactives par le TNF $\alpha$. 
41

\section{EGFR AND ERK1/2 ACTIVATION PATHWAY IS ALTERED IN BRONCHIAL EPITHELIAL CELLS IN ASTHMA}

\section{A Semlali, E Jacques, S Plante, S Biardel, J Milot, M Laviolette, LP Boulet, J Chakir \\ Centre de recherche Hôpital Laval, Sainte-Foy, Québec}

BACKGROUND: Epithelial damage is one of the many pathophysiological features of asthma. Damage to bronchial epithelium results in release of growth factors, such as EGF and TGF- $\beta_{1}$. The objective of our study is to evaluate the importance of TGF- $\beta_{1}$ in regulating epithelial cell repair in asthma.

METHODS: Epithelial cells from asthmatic and healthy subjects were cultured in the presence of TGF- $\beta_{1}$ / EGF. Cell proliferation was evaluated by BrdU incorporation. EGFR, MAPK, TGF- $\beta$ receptors, Smads, SARA and cyclin-dependant kinase inhibitors were evaluated by Western blot. TGF- $\beta_{1}$ and receptor expression were measured by RT-PCR and by ELISA. RESULTS: Proliferation of epithelial cells at baseline and after EGF stimulation was significantly reduced in bronchial epithelial cells derived from asthmatic subjects compared to epithelial cells obtained from healthy controls. EGF induced ERK1/2 phosphorylation was reduced in epithelial cells from asthmatics compared to cells from healthy controls. This was paralleled with a reduced EGFR phosphorylation. Addition of TGF- $\beta_{1}$ significantly decreased EGF-induced cell proliferation. TGF- $\beta_{1}$ gene expression and protein levels were higher in asthmatic epithelial cells compared to normal cells. This was supported by a high expression of SARA in cells derived from asthmatics compared to normal subjects. Cycline-dependent kinase inhibitors were highly expressed in asthmatic compared to normal cells at baseline and the addition of TGF- $\beta_{1}$ increased this expression. CONCLUSIONS: Our data suggests that there is a defect in EGF / TGF- $\beta$ balance in bronchial epithelial cells obtained from asthmatic subjects.

\section{2}

\section{ASSOCIATION ENTRE LE GÈNE DU RÉCEPTEUR BETA DE L'INTERLEUKINE-2 (IL2RB) ET L'HYPERRÉACTIVITÉ BRONCHIQUE ASTHMATIQUE DANS UN ÉCHANTILLON FAMILIAL DU SAGUENAY-LAC-ST-JEAN}

K Tremblay ${ }^{1,2}$, M Lemire ${ }^{3}$, D Daley ${ }^{4}$, A Montpetit ${ }^{3}$, AJ Sandford ${ }^{4}$, PD Paré $^{4}$, TJ Hudson ${ }^{3}, C$ Laprise $^{5}$

${ }^{1}$ Université Laval; ${ }^{2}$ Centre de médecine génique communautaire (UdeM); ${ }^{3}$ Centre d'Innovation Génome Québec et Université McGill, Québec; ${ }^{4}$ Université de Colombie-Britannique, British Columbia; ${ }^{5}$ Université du Québec à Chicoutimi, Québec

CONTEXTE: Le gène IL2RB (22q13.1) code pour le récepteur beta de l'interleukine (IL)-2 et est exprimé à la surface des leukocytes périphériques. La liaison de l'IL-2 à son récepteur déclenche les phénomènes d'endocytose et de transduction du signal mitotique, éléments importants dans la réponse immunitaire des cellules T. Basés sur le rôle biologique de l'IL2RB et sur la différence d'expression de ce gène dans le tissu bronchique des sujets asthmatiques comparativement aux témoins, nous émettons l'hypothèse que l'IL2RB est un gène candidat pour l'asthme et/ou ses phenotypes associés.

BUT: Effectuer une étude d'association avec les polymorphismes (SNPs) de l'IL2RB dans un échantillon familial du Saguenay formée de 209 familles apparentées à un sujet asthmatique (866 ADN) et de répliquer ces associations dans un autre échantillon de Vancouver.

RÉSULTATS: Vingt et un TagSNPs ont été évalués pour l'asthme, l'atopie, l'hyperréactivité bronchique (HRB) et le taux élevé d'IgE sériques avec le logiciel FBAT sous deux modèles génétiques. En modèle additif, aucun résultat n'est significatif après correction pour des tests multiples. En modèle dominant, les analyses montrent une association positive entre l'allèle rs2235330A et l'HRB ( $\mathrm{p}=0.00007)$. Cette association a été répliquée dans l'échantillon familial de Vancouver pour la $\mathrm{CP}_{20}$ (trait quantitatif) dans les deux modèles génétiques ( $\mathrm{p}<0.00018$ ).

CONCLUSION: Ces résultats montrent que les sujets porteurs de l'allèle IL2RB-rs2235330A ont une susceptibilité pour l'HRB. Toutefois, la génétique de l'IL2RB demeure à préciser (identification de la mutation) de même que son impact fonctionnel dans la pathophysiologie de l'asthme.

\section{3} AIRWAY REMODELLING INDUCED BY EXOGENOUS
LEUKOTRIENE D4 IN BROWN NORWAY (BN) RATS

T McGovern ${ }^{1}$, M Tamaoka, T Jo, M Hassan, JG Martin

${ }^{1}$ Meakins-Christie Laboratories, Montreal, Quebec

In animal models of allergic asthma, cysteinyl-LTs are involved in airway remodelling, including goblet cell and airway smooth muscle (ASM) hyperplasia. We wished to test the hypothesis that cys-LTs alone can induce epithelial and ASM remodelling. Naïve BN rats $(n=13)$ were challenged with $\operatorname{LTD}_{4}\left(2.0 \times 10^{-5} \mathrm{~m}\right)$ three times over a ten day period. Animals were administered either MK-571, a cysLT1 antagonist, $(n=8$; $\left.4.23 \times 10^{-5} \mathrm{~m}\right)$ or Bay-U, a mixed cysLT1/2 antagonist, $\left(\mathrm{n}=8 ; 5.58 \times 10^{-5} \mathrm{~m}\right)$ intra-tracheally one hour prior to each $\mathrm{LTD}_{4}$ challenge. The rats were sacrificed 48 hours following the final challenge. LTD $_{4}$ challenged rats showed significantly more inflammatory cells (eosinophils and macrophages) in bronchoalveolar lavage compared to PBS challenged animals $(\mathrm{p}=0.001)$. In rats pre-treated with MK or BAY, there was a significant decrease of BAL cells $(p=0.005, p=0.004$, respectively). The significant increase in goblet cell hyperplasia ( $\mathrm{p}=0.006$; PAS staining) in $\mathrm{LTD}_{4}$ challenged animals was prevented by MK $(\mathrm{p}=0.01)$ and BAY $(\mathrm{p}=0.007)$. Proliferating cell nuclear antigen (PCNA) and $\alpha$-actin smooth muscle double immunostaining was performed on lung sections. The number of proliferating airway epithelial cells and the area of ASM showed a significant increase in animals challenged with $\mathrm{LTD}_{4}$ as compared to animals challenged with PBS ( $p=9.91 \mathrm{E}-05$ and $\mathrm{p}=0.044$, respectively). Expression of heparin-binding epidermal growth factor (HB-EGF), an EGF ligand and potential contributor to remodelling, showed a significant increase in the epithelium of $\mathrm{LTD}_{4}$ challenged rats by quantitative realtime RT-PCR $(\mathrm{p}=0.022)$. Our findings suggest that challenge with $\mathrm{LTD}_{4}$ is sufficient to induce asthma-like airway remodelling in vivo, potentially through the EGFR pathway. $\mathrm{LTD}_{4}$ induced changes can be blocked by antagonists of the cysLT1 receptor.

Funded by medical school grant from Merck Inc and Canadian Institutes of Health Research

\section{4}

\section{EFFETS IMMUNOMODULATOIRES DE LA FUMÉE DE CIGARETTE SUR LES CELLULES ÉPITHÉLIALES BRONCHIQUES}

\section{ISt-Laurent, LP Boulet, E Bissonnette}

Unité de recherche en pneumologie, Centre de recherche de I'Hôpital Laval. Institut universitaire de cardiologie et de pneumologie, Québec, Quebec

INTRODUCTION: Les cellules épithéliales contribuent à la défense du poumon contre différents stimuli environnementaux. La fumée de cigarette contient des substances toxiques qui peuvent altérer les fonctions de l'épithélium bronchique.

BUT: Investiguer la libération de MCP-1 et de l'IL-10 ainsi que l'expression de cytokines inflammatoires (IL-1 $\alpha$, IL-1 $\beta$, IL-1ra, IL-6, TNF- $\alpha$, IL-12p40 et GM-CSF) sur les cellules épithéliales bronchiques après 5 jours d'exposition à la fumée de cigarette.

MÉTHODES: Des cellules épithéliales bronchiques provenant de rat (NRBE) ont été exposées à la fumée de cigarette en utilisant deux modèles. Le premier consistait à exposer les cellules à l'extrait de fumée de cigarette (EFC) obtenu à l'aide d'un échantillonneur d'air. Les cellules ont été placées en culture cellulaire et exposées l'EFC à tous les jours pendant 5 jours. Le deuxième modèle consistait à exposer les NRBE, cultivées en interface air/liquide, à la fumée de cigarette dans une chambre d'exposition. RÉSULTATS: Les NRBE exposées à l'EFC démontraient une augmentation significativement croissante de la production de MCP-1 durant 5 jours $(\mathrm{p}=0,01)$. De plus, la libération de l'IL-10 était significativement réduite par l'EFC aux jours 4 et 5 comparativement aux cellules contrôles. Le deuxième modèle permettait d'obtenir une inhibition significative de la production de MCP-1 et d'IL-10 chez les cellules exposées à la fumée de cigarette comparativement aux cellules contrôles. $(p=0,01)$. Aucune différence n'a été observée dans l'expression des cytokines pro- et antiinflammatoires entre nos deux groupes. 
CONCLUSION: Les deux modèles d'exposition à la fumée de cigarette stimulent de manière différente la production de MCP-1 par les cellules épithéliales bronchiques. De plus, la libération de l'IL-10, une cytokine anti-inflammatoire, est inhibée par la fumée de cigarette.

\section{5}

\section{CARACTÉRISATION PHÉNOTYPIQUE DES MACROPHAGES ALVÉOLAIRES CHEZ DES SUJETS ATTEINTS D'ASTHME ALLERGIQUE}

AM Madore ${ }^{1,2}$, V Turmel $^{3}$, M Laviolette ${ }^{1,3}$, E Bissonnette $^{1,3}$, C Laprise ${ }^{2,4}$

${ }^{1}$ Université Laval; ${ }^{2}$ Centre de médecine génique communautaire de I'Université de Montréal; ${ }^{3}$ Unité de recherche en pneumologie, Hôpital Laval; ${ }^{4}$ Université du Québec à Chicoutimi, Québec

CONTEXTE: Les macrophages alvéolaires (MA) sont considérés comme la ligne de défense majeure des poumons. Jusqu'ici, les études n'ont permis qu'à identifier une mince proportion des déterminants génétiques et voies biologiques qui définissent l'implication des MA dans l'asthme et l'atopie. OBJECTIFS: 1) Étudier le transcriptome des MA à l'aide de puces à ADN Affymetrix HG-U133A; 2) Cibler de nouveaux biomarqueurs pour l'asthme et l'atopie; 3) Sélectionner 5 gènes et valider les résultats de puce par RT-PCR en temps réel.

MÉTHODE: L'extraction de l'ARN des MA issus de 5 sujets asthmatiques allergiques et de 5 sujets témoins (sans asthme ni allergie) a été effectuée suite à leur isolation à partir de lavages bronchoalvéolaires. Une liste de biomarqueurs spécifiques à l'activité des MA dans l'asthme allergique a été élaborée après l'analyse des résultats des puces à ADN et l'ARN a été utilisé afin de valider les résultats obtenus pour 5 gènes par RT-PCR en temps réel.

RÉSULTATS: Trente-quatre gènes, classés dans 9 types de fonctions biologiques, ont été différemment exprimés par les MA des sujets asthmatiques allergiques par rapport aux MA des sujets témoins selon l'analyse des puces à $\mathrm{ADN}$. Les résultats obtenus pour 3 des 5 gènes sélectionnés (HSPD1, PRNP, SERPINH1) ont été validés par RT-PCR en temps réel. PERSPECTIVES: La caractérisation de l'expression protéique à l'aide de l'immunocytochimie et du Western blot pour les protéines correspondant aux 3 gènes validés est en cours. Des études fonctionnelles seront effectuées pour une de ces protéines à partir de cultures cellulaires de MA afin de caractériser la voie biologique dans laquelle est intégrée cette protéine.

\section{6}

\section{IMPACT DES OXYDANTS SUR DES MODÈLES IN VIVO ET IN VITRO DE LÉSIONS PULMONAIRES}

\section{Chupin ${ }^{1}$, A Privé ${ }^{1}$, P Barbry², E Brochiero ${ }^{1}$, Y Berthiaume ${ }^{1}$}

${ }^{1}$ Département de Médecine, Facuté de Médecine, Université de Montréal, Québec; ${ }^{2}$ IPMC-CNRS, Université Nice-Sophia Antipolis, France

Les lésions pulmonaires, quelque soit leur origine, sont associées à des processus inflammatoires et de remodelage. Le but de ce travail est de développer des modèles in vivo et in vitro qui permettent d'étudier les mécanismes impliqués dans le processus de remodelage lors d'un stress oxydatif.

Nous avons utilisé un modèle lésionnel induit par la bléomycine, car cet agent anticancéreux entraîne la formation d'un oedème pulmonaire en provoquant des lésions épithéliales par un stress oxydatif.

In vivo, nous avons montré que les souris $\mathrm{C} 57 \mathrm{bl} / 6 \mathrm{j}$ sensibles à l'instillation intratrachéale de bléomycine $(1,5 \mathrm{U} / \mathrm{kg})$ présentent un œdème dès 3 jours $(\mathrm{p}=0,006)$, s'amplifiant à 15 jours $(\mathrm{p}=0,00016)$, associé à une inflammation caractérisée par $22 \%$ de neutrophiles à 3 jours et $32 \%$ de lymphocytes à 15 jours.

Pour reproduire ce modèle de lésions in vitro, nous avons procédé à des lésions mécaniques de cellules épithéliales alvéolaires de rat en présence de bléomycine. L'effet de la bléomycine $(12,5-150 \mathrm{mU} / \mathrm{ml})$ sur la fermeture des plaies de 24 à $48 \mathrm{~h}$, montrent une inhibition dose et temps dépendants $(p<0,0001)$. Cet effet est reproduit en utilisant un autre oxydant, le DMNQ $(10 \mu \mathrm{M} ; \mathrm{p}<0,01)$. La réparation épithéliale dépend de processus de migration, prolifération et différentiation. Nous montrons, en utilisant une chambre de migration de style Boyden, que le DMNQ inhibe la migration à $90 \%(\mathrm{p}<0,05)$.

Nos modèles in vivo et in vitro, nous permettent de démontrer l'impact des oxydants sur les lésions et la réparation de l'épithélium pulmonaire. Par la suite nous étudierons l'impact du canal $\mathrm{ENaC}$, qui est impliqué dans les processus de résolution de l'œdème et de différentiation cellulaire.

\section{7}

\section{L'ÉLÉVATION CHRONIQUE DE CORTICOSTÉRONE AUGMENTE LA RÉPONSE VENTILATOIRE À L'HYPOXIE CHEZ LE RAT ADULTE}

F Sébastien, A Mathieu, G Roumiana, K Richard

Département de Pediatrie, Centre de Recherche Hospitalier Universitaire de Québec, Université Laval, Québec

OBJECTIFS: La séparation maternelle néonatale (SMN) est une forme de stress qui dérange le fonctionnement de l'axe hypothalamo-hypophysosurrénalien (HPA) (Genest et al., 2004) résultant en une élévation chronique du niveau de corticostérone dans le plasma du rat adulte. Cette élévation est sexe-spécifique et est exprimée uniquement chez le rat mâle. La SMN provoque d'autres problèmes physiologiques tels que l'augmentation du chemoréflexe à l'hypoxie par des mécanismes qui demeurent, à ce jour, inconnus. Cette étude teste l'hypothèse selon laquelle l'augmentation chronique des niveaux de corticostérone plasmatique augmente la réponse ventilatoire à l'hypoxie.

MÉTHODES: Les rats assujettis à une élévation de corticostérone ont reçu 300 mg d'un implant de corticostérone sous-cutané 14 jours avant le début de l'enregistrement ventilatoire, alors que les rats placebo recevaient un implant placebo. Des échantillons de sang prélevés après l'expérience ont permis de valider notre protocole. Les mesures ventilatoires ont été effectuées par pléthysmographie en condition de base (normoxie) et en hypoxie modérée $\left(12 \% \mathrm{O}_{2}\right)$. L'impact du sexe sur ces effets a été évalué en comparant les résultats obtenus chez les mâles versus ceux des femelles.

RÉSULTATS: Les rats implantés avec de la corticostérone ont démontrés une réponse ventilatoire à l'hypoxie plus élevé que celle des rats placebos et contrôles et ce, tant chez les rats mâles que femelles.

CONCLUSION: Ces données démontrent qu'une élévation chronique de corticostérone exogène affecte, à elle seule, la réponse ventilatoire à une hypoxie modérée de $12 \%$, et ce tant pour les mâles que les femelles. Ceci suggère qu'une élévation chronique de corticostérone pourrait donc contribuer au phénotype respiratoire observé auprès des rats NMS.

\section{8}

\section{COUPLAGE ENTRE L'ACTIVITÉ DES CANAUX K ${ }^{+}$ET L'EXPRESSION DES CANAUX ENaC ET CFTR DANS LES CELLULES ALVÉOLAIRES}

\section{IC Bourret, C Leroy, A Privé, E Brochiero}

\section{Centre de recherche CHUM Hôtel-Dieu, Montréal, Québec}

INTRO: De façon générale, les canaux $\mathrm{K}^{+}$maintiennent un gradient électrochimique favorable au transport ionique dans les épithélia. Au niveau de l'épithélium alvéolaire, nous avons montré que l'activité des canaux KvLQT1, $K_{\mathrm{Ca}}$ et $\mathrm{K}_{\mathrm{ATP}}$ est impliquée pour les transports transépithéliaux de $\mathrm{Na}^{+}$et de $\mathrm{Cl}^{-}$accomplis principalement par les canaux ENaC et CFTR. De plus, il a été démontré lors d'expérimentation ex vivo qu'un traitement prolongé avec un activateur du canal $\mathrm{K}_{\mathrm{ATP}}$ augmentait la clairance alvéolaire, probablement en stimulant le transport de $\mathrm{Na}^{+}$. Nous avons donc posé l'hypothèse que l'activité ou l'expression de ENaC et CFTR pourrait être régulée à long terme par les canaux $\mathrm{K}^{+}$.

RÉSULTATS: Nous avons ainsi fait une observation originale, des traitements chroniques avec des inhibiteurs des canaux $\mathrm{K}_{\text {ATP }}$ et KvLQT1 (glibenclamide et clofilium) diminuent fortement les courants $\mathrm{Na}^{+}$et $\mathrm{Cl}^{-}$ (via ENaC et CFTR) tandis que le pinacidil (activateur du $\mathrm{K}_{\mathrm{ATP}}$ ) les stimule. De façon intéressante, les inhibiteurs du $\mathrm{K}_{\text {ATP }}$ et KvLQT1 diminuent aussi l'expression génique et protéique de $\mathrm{ENaC}$ et CFTR, tandis que le pinacidil les stimule. Nous avons ensuite testé l'impact de ces modulateurs sur l'absorption des fluides alvéolaires : le glibenclamide et le clofilium réduisent l'absorption des fluides tandis que le pinacidil l'augmente. CONCLUSION : En contrôlant ainsi l'activité et l'expression des canaux 
ENaC et CFTR et en modulant le transport des fluides, l'activité des canaux $\mathrm{K}^{+}$semble donc jouer un rôle primordial dans la physiologie épithéliale pulmonaire et pourrait également être un atout majeur pour la résolution de maladies caractérisées par un dysfonctionnement du transport d'ions et de fluides.

\section{9}

\section{CRYOTHERAPY AND CHEMOTHERAPY IN THE TREATMENT OF HUMAN LUNG CANCER}

\section{Forest}

Centre de Recherche du Centre Hospitalier de l'Université de Montréal, Montréal, Québec

BACKGROUND: Cryotherapy, a method based on the cytotoxic effects of cold is sometimes used in the palliative treatment of lung cancers. But it can also be used as an adjuvant therapy.

PURPOSE: The aim of this study was to analyze in vivo the biological effects of cryotherapy and chemotherapy, performed alone or in combination in a model of human lung cancer.

METHODS: Cells from the A549 cell line (adenocarcinoma) were xenografted into SCID mice. Tumors obtained were treated by cryotherapy (nitrous oxide), chemotherapy (Vinorelbine) or both.

RESULTS: The two therapies presented very different features: 1) different mechanisms of action: cryotherapy directly induced cell death whereas chemotherapy rather acted by inhibiting cell proliferation, 2) a different chronology of action: cryotherapy presented two peaks of maximal efficiency in the induction of cell death (related to its dual mechanism of action), on the contrary, chemotherapy presented a constant efficiency, and finally 3) different locations of their effects: cryotherapy mainly acted at the centre of the cryoinjury while chemotherapy acted at the tumor periphery where vascularization is maximal. When these two therapies were combined, the induction of cell death was significantly increased (by necrosis but above all by apoptosis) early after treatment. Finally, mice treated by cryochemotherapy presented a more important decreased tumor volume than mice treated by cryotherapy or chemotherapy performed separately. In conclusion, cryotherapy and chemotherapy present complementary effects and their combination offers a benefit in the induction of cell death which is correlated with a reduced tumor growth.

\section{0}

\section{TEST DE MARCHE DE SIX MINUTES VERSUS MARCHE NAVETTE D'ENDURANCE : SENSIBILITÉ À LA BRONCHODILATATION DANS LA MPOC}

$\underline{V}$ Pepin $^{1}$, J Brodeur ${ }^{2}$, F Whittom ${ }^{2}$, Y Lacasse ${ }^{2}$, J Milot ${ }^{2}$, P LeBlanc ${ }^{2}$, F Maltais ${ }^{2}$

${ }^{1}$ Axe de recherche en santé respiratoire, Hôpital du Sacré-Cœur de Montréal, Montréal; ${ }^{2}$ Centre de recherche en pneumologie, Hôpital Laval, Québec

INTRODUCTION: Nous avons récemment démontré que le test de marche navette d'endurance était sensible aux changements induits par la bronchodilation. La littérature suggère qu'il en est autrement pour le test de marche de six minutes (6MDM).

OBJECTIF: Comparer les changements de performance obtenus suite à l'administration d'un bronchodilatateur entre le 6MDM et la marche navette d'endurance chez des patients atteints de MPOC.

MÉTHODOLOGIE: Quatorze patients MPOC (VEMS: $50 \pm 8 \%$ de la prédite) ont complété deux 6MDM et deux marches navette d'endurance, tous précédés par la nébulisation d'un placebo (PL) ou de $500 \mu \mathrm{g}$ de bromure d'ipratropium (BI) suivant un devis croisé, randomisé et à doubleaveugle. Les paramètres cardiorespiratoires ont été examinés à l'aide d'un système portable télémétrique (K4b2 , Cosmed, Italie). La force du quadriceps a été mesurée avec la stimulation magnétique du nerf fémoral avant et après chaque test de marche.

RÉSULTATS: La distance marchée au 6MDM ne s'est pas améliorée suite à la bronchodilatation malgré une augmentation significative du VEMS $(0,18 \pm 0,09 \mathrm{~L}, \mathrm{p}<0,001)$. Un changement semblable du VEMS ( $\triangle$ VEMS: $0,18 \pm 0,12 \mathrm{~L}, \mathrm{p}<0,001)$ s'est accompagné d'une augmentation significative de la distance marchée au test de marche navette d'endurance ( $\Delta$ distance
BI-PL: 144 \pm 219 mètres, $p=0,03)$. La fatigue contractile du quadriceps s'est avérée peu fréquente $(<15 \%$ des cas) après les deux tests.

CONCLUSION: La marche navette d'endurance est plus sensible que le $6 \mathrm{MDM}$ pour détecter des améliorations fonctionnelles suite à la bronchodilatation. Des différences au niveau du devis des tests pourraient en partie expliquer ces différences de sensibilité au changement.

\section{1}

\section{ADJUVANT CHEMOTHERAPY IN RESECTED LUNG CANCER: TWO-YEAR EXPERIENCE AT LAVAL HOSPITAL}

N Bouchard, F Laberge, B Raby, S Martin, Y Lacasse

Pneumology center, Hopital Laval, Quebec

BACKGROUND: Randomized trials have confirmed the benefits of adjuvant chemotherapy in improving survival in resected early-stage nonsmall cell lung cancer (NSCLC). The extent to which these results have translated into clinical practice is unknown.

OBJECTIVES: (1) To examine the referral patterns of patients with resected lung cancer to adjuvant chemotherapy, and (2) to compare compliance and toxicities to the current literature.

METHODS: We conducted a retrospective analysis of all patients who underwent a surgical resection for lung cancer at Laval Hospital from March 2004 to June 2006.

RESULTS: 258 patients underwent surgery. We excluded 7 patients because of early post-operative death and 2 because of incomplete data. Data from 249 patients were analyzed (94\% NSCLC). 50\% were referred to medical oncology for consideration of adjuvant chemotherapy, including 37 of 61 patients with stage 2 NSCLC. One hundred received chemotherapy. We found significant difference in stage cancer, performance status and age between those who received chemotherapy and those who did not. More advanced stages, worst performance status and older patients were less likely to receive chemotherapy. However, we found no significant difference in gender, comorbidities and surgical procedures. Chemotherapy was initiated 47 days (median) after the surgery and consisted mainly of cisplatin-vinorelbine (38\%), cisplatin-etoposide (22\%), carboplatin-paclitaxel (20\%) and cisplatin-gemcitabine (13\%). $66 \%$ of the patients completed all four cycles. Grade 3 or 4 toxicities consisted mainly of fatigue $(23 \%)$ and cytopenia $(40 \%)$. No death was registered; $14 \%$ had to be hospitalized because of adverse effects.

CONCLUSION: Adjuvant chemotherapy is gaining acceptance in clinical practice. Compliance and toxicity are similar or better than those described in published randomized trial.

\section{2}

\section{PLEURAL EFFUSIONS FOLLOWING MYOCARDIAL REVASCULARIZATION SURGERY: PREVALENCE, RISK FACTORS AND CLINICAL CHARACTERIZATION}

M Labidi, F Maltais, R Baillot, B Dionne, Y Lacasse, LP Boulet Institut universitaire de cardiologie et de pneumologie, Université Laval, Hôpital Laval, Quebec

RATIONALE: Pleural effusion (PEf) is a common complication of coronary artery bypass grafting (CABG) surgery. The characteristics of these effusions, the mechanisms involved and the predisposing factors remain to be further examined.

OBJECTIVES: To determine the prevalence, characteristics and determinants of clinically significant PEf (CSPEf), defined as PEf that required a therapeutic thoracentesis or pleural drainage.

METHODS: This was a retrospective database study of patients who had a CSPEf over a period of 12 months after CABG surgery, valve replacement (VR) or both interventions in our institution between January 2004 and December 2005. We compared patients who developed PEf to those who did not.

RESULTS: Among the 2892 patients included in our study (mean age: 66 years; 2139 men), 213 had a CSPEf (7.4\%). PEf were noted after 5.0 days (median) following surgery and mean volume of pleural fluid withdrawn was $680 \mathrm{ml}$. Among the 124 patients who had their pleural fluid (PF) analyzed, the criteria for an exudate was fulfilled in 121 (98\%) patients. PF was considered hemorrhagic in $49 \%$. Age, body weight, ejection fraction, 
baseline pulmonary function and smoking status were similar between patients who presented CSPEf and those who did not. However, the proportion of women and patients with a previous diagnosis of heart failure was increased in CSPEf. Patients with CSPEf had an increased number of other post-operative complications.

CONCLUSION: CSPEf is a common complication of cardiac surgery, is associated with other post-operative complications and is more frequent in patients with a previous diagnosis of heart failure and in women. Local funds

\section{3}

\section{PÉRCARDITE CONSTRICTIVE CHEZ UN PATIENT AVEC AMIANTOSE PULMONAIRE}

$\underline{K}$ Chagnon $^{1}$, A Cartier ${ }^{1}$, A Desjardins ${ }^{1}$, R Amyot $^{2}$

${ }^{1}$ Département de pneumologie, Hôpital du Sacré-Cour de Montréal; ${ }^{2}$ Département de pneumologie, Pavillon Hôtel-Dieu du CHUM, Montréal, Québec

INTRODUCTION: Des pathologies pleurales inflammatoires ou fibreuses sont fréquemment observées suite à une exposition à l'amiante. L'atteinte péricardique est, par contre, exceptionnelle. Nous rapportons, ici, un cas de péricardite constrictive amiantosique.

OBSERVATION CLINIQUE: Il s'agit d'un homme de 59 ans, ancien fumeur, ayant subi une exposition sporadique à l'amiante de 1965 à 1967, lors de travaux de maintenance dans une raffinerie de pétrole. À l'été 2004, il fut hospitalisé pour une péricardite aiguë, dont une étiologie virale avait été retenue. La radiographie pulmonaire démontrait des plaques pleurales calcifiées bilatéralement. Au cours de l'année, il développa une dyspnée progressive, un gain pondéral associé à un gonflement abdominal. L'examen physique révélait une tension veineuse centrale élevée et une hépatomégalie. L'investigation par échographie et cathétérisme cardiaque a mis en évidence des signes de constriction péricardique sévère. La tomodensitométrie thoracique a confirmé la présence d'épaississement péricardique, de plaques pleurales calcifiées, de prolongements fibreux intra-parenchymateux bilatéraux avec un début d'atélectasie ronde, et une fibrose sous-pleurale bi-basale. Le patient a alors subi une péricardectomie totale. L'examen pathologique a démontré un péricarde épaissi et fibreux, compatible avec une péricardite constrictive non spécifique. Le patient évolua favorablement suite à l'intervention chirurgicale.

CONCLUSION: Chez un patient avec une péricardite constrictive, une exposition antérieure à l'amiante et des séquelles pleuro-pulmonaires compatibles, le diagnostic de péricardite amiantosique devrait être considéré.

\section{4}

\section{UNDERREPORTING ACUTE EXACERBATION IN PATIENTS WITH COPD: INCIDENCE AND PREDICTORS}

$\underline{L}$ Langsetmo $^{1}$, R Platt ${ }^{2}$, P Ernst $^{2}$, J Bourbeau ${ }^{1}$

${ }^{1}$ Respiratory Epidemiology and Clinical Research Unit, Montreal Chest Institute; ${ }^{2}$ Clinical Epidemiology, Royal Victoria Hospital, McGill University, Montreal, Quebec

BACKGROUND: COPD exacerbations are recognized as serious events. It has been shown in one study [East London Cohort] that close to half of all exacerbations remain unreported and untreated. Further assessment of unreported exacerbations and predictors is needed to help determine the population at risk.

OBJECTIVE: To determine how patterns of respiratory symptom change, patient behavior, and health status are related among community dwelling patients with moderate to severe chronic obstructive pulmonary disease (COPD) and history of exacerbations.

METHODS: The study population was a cohort of 421 communitydwelling Canadians with moderate to severe COPD and a history of at least two exacerbations enrolled in a six-month single-arm drug trial. The daily diary was assessed for change in at least one of the key symptoms associated with exacerbation (dyspnea, sputum quantity, and sputum color). Daily diary events were any sustained increase of key symptoms that were recorded on at least two consecutive days. Participants were instructed to call the study center upon any respiratory symptom change of more than 24 hours. An event was reported if it resulted in an exacerbation phone call or was otherwise reported to the study center. Predictors of reporting were assessed using a Cox proportional hazards model.

RESULTS: 177 people reported at least one exacerbation for a total of 234 exacerbations. 225 people recorded at least one sustained increase in a key symptom for a total of 522 events. Approximately two-thirds of all events ascertained from the daily diary were not reported, and that $60 \%$ of events with at least two symptoms were not reported. The lowest reporting rate was found among the events with increased dyspnea, and the highest reporting rate was found among the events with change in sputum color. Reporting an event was associated with number of respiratory symptoms (HR: 1.58, 95\% CI: 1.37-1.81), use of rescue medication (HR: 1.18, 95\% CI: 1.01-1.37), baseline $\mathrm{FEV}_{1}$ (HR: 0.83, 95\% CI: 0.70-0.99), and weekend versus weekday (HR: 0.33, 95\% CI: 0.21-0.53).

CONCLUSION: There was a high incidence of unreported symptom change with changes in multiple respiratory symptoms among patients with moderate to severe COPD. The associated failure to receive treatment for these events represents a serious unmet health need.

The study was sponsored by Astra-Zeneca

\section{5}

AMELIORATION DE LA FORCE MUSCULAIRE DU QUADRICEPS ET DE LA CAPACITE FONCTIONNELLE APRES UN REENTRAINEMENT EN ENDURANCE DE 3 MOIS À DOMICILE CHEZ DES PATIENTS TRANSPLANTES PULMONAIRES

I Vivodtzev, C Pison, P Mezin, E Maclet, K Guerrero, JC Borel, P Levy, B Wuyam

Laboratoire EFCR, HP2, INSERM ERI 0017 \& Département de Médecine Aiguë Spécialisée, Centre Hospitalier Universitaire de Grenoble, France

INTRODUCTION: Chez les patients transplantés pulmonaires (LTR) dont la fonction pulmonaire est quasi-normalisée, il existe une faiblesse musculaire et une intolérance à l'effort reconnues. Pourtant, très peu d'études ont investigué l'effet d'une réadaptation à l'effort chez ces patients. BUT: Evaluer l'effet d'un réentraînement à domicile de 3 mois chez 12 patients LTR (VEMS $=74 \pm 24 \%$ prédite) et 12 sujets sains contrôles. METHODES: La force non-coopérante du quadriceps induite par stimulation magnétique du nerf fémoral, les caractéristiques des fibres musculaires (biospies vaste externe), les réponses métaboliques et ventilatoires (VE) à l'effort sur cycloergomètre et la qualité de vie (Chronic Respiratory Questionnaire CRQ) ont été évalués avant et après réentraînement.

RESULTATS: Initialement, les patients LTR présentaient une réduction du pourcentage de fibres de type $I$, de $T w Q$, de la puissance maximale atteinte $\left(\mathrm{P}_{\max }\right)$, de $\mathrm{VE}_{\max }$ et du temps d'endurance (Tlim). Apres réentraînement, TwQ $(+44 \pm 26 \mathrm{~N}), \mathrm{P}_{\max }(+13 \pm 19 \mathrm{~W}), \operatorname{Tlim}(+11.5 \pm 11.1$ $\min )$ et le score de dyspnée au CRQ (CRQ dyspnée $+3.1 \pm 4.4$ points) étaient augmentés et VE réduite $(-6.4 \pm 5.2 \mathrm{~L} / \mathrm{min})$ chez les LTR $(\mathrm{p}<0.05)$. Les modifications de fatigue post-endurance et de VE à iso watt et celles de TwQ et de CRQ $Q_{\text {dyspnea }}$ étaient corrélées chez les LTR $(r=0.72, p=0.06$ et $\mathrm{r}=0.74, \mathrm{p}=0.04$, respectivement).

CONCLUSION: Le réentraînement a conduit à une amélioration de la tolérance à l'effort, de la force musculaire et de la qualité de vie. Les améliorations au niveau musculaire périphérique pourraient contribuer à réduire la ventilation à l'effort et/ou la dyspnée au cours des activités quotidiennes.

\section{6}

LES TROUBLES PSYCHIATRIQUES ET LE TAUX D'EXACERBATIONS AIGUÊS CHEZ LES PATIENTS SOUFFRANT DE MPOC

C Laurin $^{1,2}$, KL Lavoie ${ }^{1,2}$, SL Bacon ${ }^{1,3}$, A Bouchard ${ }^{1,2}$, G Dupuis ${ }^{2}$, A Cartier $^{1,4}$, M Labrecque $^{1,4}$

${ }^{1}$ Axe de recherche en santé respiratoire, Hôpital du Sacré-Coeur de Montréal; ${ }^{2}$ Université du Québec à Montréal (UQAM); ${ }^{3}$ Université Concordia; ${ }^{4}$ Université de Montréal, Québec

INTRODUCTION: La maladie pulmonaire obstructive chronique (MPOC) est associée à l'apparition intermitente d'exacerbations. Bien que 
les troubles psychiatriques soient présents chez 16 à $51 \%$ des patients, aucune étude connue n'a évalué l'association entre de telles comorbidités et le taux d'exacerbations.

OBJECTIF: Évaluer la capacité des troubles d'anxiété et de l'humeur à prédire le moment d'apparition des exacerbations non sévères (traitées à la maison) et sévères (hospitalisations et visites à l'urgence) chez les patients souffrant d'une MPOC documentée.

MÉTHODE: 116 patients (âge moyen: 67 ans) en état stable ont réalisé une spirométrie et ont répondu à une entrevue sociodémographique, médicale et psychiatrique (ADIS-IV). Un suivi mensuel téléphonique d'un an a été réalisé pour évaluer la fréquence des exacerbations non sévères et une revue du dossier médical a été faite en moyenne 2,2 ans après l'entrevue initiale pour vérifier la fréquence des exacerbations sévères.

RÉSULTATS: Les patients souffrant de troubles psychiatriques ont présenté une première exacerbation non sévère significativement plus rapidement que ceux sans trouble psychiatrique $\left(\log\right.$-rank $\left.\chi^{2}=4,82 ; \mathrm{p}=0,028\right)$ et ont également eu tendance à présenter une deuxième exacerbation non sévère plus rapidement $\left(\log\right.$-rank $\left.\chi^{2}=3,59 ; \mathrm{p}=0,058\right)$. La première $(\log$ rank $\left.\chi^{2}=0,62 ; \mathrm{p}=0,430\right)$ et la deuxième exacerbations sévères (log-rank $\left.\chi^{2}=0,96 ; \mathrm{p}=0,330\right)$ ne sont pas apparues significativement plus rapidement chez les patients souffrant de troubles psychiatriques.

CONCLUSION: Les patients présentant des troubles psychiatriques ont souffert plus rapidement d'une première et d'une deuxième exacerbations traitées à la maison que ceux sans troubles psychiatriques. Des études prospectives évaluant la morbidité psychiatrique permettraient de mieux comprendre la direction de la relation entre les troubles psychiatriques et les exacerbations.

\section{7}

\section{LA FATIGABILITÉ DES MUSCLES DE LA LOCOMOTION LORS DE LA MARCHE 6 MINUTES DANS LA MPOC}

$\underline{\text { N Marquis }}^{1}$, L Bouyer ${ }^{2}$, R Debigaré $^{1}$, L Laviolette $^{1}$, C Brouillard $^{1}$, D Saey $^{3}$, F Maltais ${ }^{1}$

${ }^{1}$ Centre de recherche, Hôpital Laval, Sainte-foy; ${ }^{2}$ CIRRIS, Québec; ${ }^{3}$ Université Catholique de Leuven, Leuven, Belgique

PROBLÉMATIQUE: Les patients atteints d'une MPOC perçoivent moins de fatigue musculaire au niveau du quadriceps à la marche qu'au vélo stationnaire. La fatigue musculaire dans les autres muscles impliqués à la marche n'est pas connue. Le but de cette étude est d'évaluer l'activité musculaire de cinq muscles du membre inférieur chez 11 sujets sains et 10 sujets MPOC, lors d'un test de marche 6-minutes.

MÉTHODOLOGIE: Des données d'électromyographie de surface (SEMG) ont été enregistrés dans cinq muscles (soleus, gastrocnemius (GM), tibialis anterior, vastus lateralis et rectus femoris), lors d'un test de marche. La fréquence médiane de l'EMG pour toutes les contractions musculaires a été analysée à la minute 2 et 6 du test de marche pour chaque muscle. La ventilation, la consommation d'oxygène et la production de $\mathrm{CO}_{2}$ ont également été mesurées tout le long du test.

RÉSULTATS: Même si on observe une distance $(494 \pm 116$ vs $625 \pm 50 \mathrm{~m}$; $\mathrm{p}<0.01)$ et une vitesse de marche $(1.7 \pm 0.4$ vs $2.1 \pm 1.2 \mathrm{~m} / \mathrm{s} ; \mathrm{p}<0.01)$ réduites chez les MPOC par rapport aux sujets sains, les patients travaillent à un plus haut pourcentage de leur ventilation volontaire maximale estimée pendant le test $(118 \pm 32 \%$ vs $51 \pm 14 ; \mathrm{p}<0.01)$. La fréquence médiane analysée de la minute 2 à la minute 6 du test de marche, diffère entre les patients MPOC et les sujets contrôles pour le soleus, GM, tibialis anterior, suggérant la présence de fatigue musculaire chez les MPOC.

CONCLUSION: Des évidences de fatigue musculaire ont été retrouvées dans 3 groupes musculaires de la jambe pendant la marche chez les MPOC, malgré que le test a été réalisé à une intensité moindre chez les sujets MPOC comparé aux individus sains.

\section{8}

LA REPONSE DU TEST DE MARCHE DE 6-MINUTES ET DU

TEST D'ENDURANCE SUR ERGOCYCLE SUITE A UN PROGRAMME DE RÉADAPTATION PULMONAIRE ET UN SUIVI D'UN AN CHEZ DES PATIENTS ATTEINT DE MPOC.

$\underline{\text { L Laviolette }}^{1}$, J Bourbeau ${ }^{2}$, Y Lacasse ${ }^{1}$, S Bernard $^{1}$, MJ Breton ${ }^{1}$, M Rouleau $^{3}$, MA Gadoury ${ }^{3}$, F Maltais ${ }^{1}$

${ }^{1}$ Centre de Recherche, Hôpital Laval, Institut universitaire de cardiologie et de pneumologie de I'Université Laval; ${ }^{2}$ Respiratory Epidemiology and Clinical Research Unit, McGill University and Montreal Chest Institute of the Royal Victoria Hospital, McGill University Health Centre, Montreal; ${ }^{3}$ Hôpital du Saint-Sacrement, Centre Universitaire affilié de L'Université Laval, Québec

La maladie pulmonaire obstructive chronique (MPOC) se caractérise par une sévère limitation de la tolérance à l'effort. La réadaptation pulmonaire accroit La tolérance à l'effort, mais on connaît peu de son impact comparatif sur le test de marche de 6 minutes (TM6) et le test d'endurance sur ergocycle (TEE). De plus, la signification clinique de ces changements de tolérance à l'effort demeure imprécise. Nous avons comparé les variations du TM6 et du TEE suite à un programme d'exercice de 12 semaines et un suivi d'un an chez des patients atteints de MPOC. De plus, nous avons investigué la relation entre ces variations et La qualité de vie.

MÉTHODE: Des patients atteints de MPOC (âge: $64 \pm 8$ années, moyenne \pm SD; VEMS: $45,4 \pm 15,4 \%$ préd) ont été évalué avant et après un programme d'exercice de 12 semaines $(\mathrm{n}=158)$ ainsi qu'un an plus tard $(\mathrm{n}=120)$. Le TM6, le TEE et le questionnaire de St-Georges (SGRQ) ont été réalisés à chaque visite.

RÉSULTATS: Le TEE $(212 \pm 369$ s $)$ et le TM6 $(25 \pm 52 \mathrm{~m})$ se sont significativement améliorés $(\mathrm{p}<0,0001)$ sans être corrélés. Lorsque exprimée en $\%$ des valeurs de départ, le TEE s'est davantage amélioré que le TM6 $(182 \pm 135$ vs $108 \pm 17 \%, \mathrm{p}<0,0001)$. Les variations du TEE étaient plus corrélées avec Les changements du SGRQ que le TM6. Après 1 année, les valeurs du TM6 étaient revenues à celles du départ, alors qu'une amélioration persistait dans le TEE $(\mathrm{P}<0,0001)$.

CONCLUSION: Le TEE répond davantage a la réadaptation pulmonaire que le TM6 et il est plus associé aux variations du SGRQ. Seuls les progrès du TEE demeurent après une année de suivi. Ces résultats appuient la notion que ces deux tests mesurent des construits différents.

\section{9}

RELATION ENTRE L'ATHÉROSCLÉROSE CORONAIRE ET LE SYNDROME D'APNÉE HYPOPNÉE DU SOMMEIL : UNE ÉTUDE D'ÉCHOGRAPHIE INTRAVASCULAIRE

L Turmel ${ }^{1}$, F Sériès ${ }^{1}$, LP Boulet ${ }^{1}$, P Poirier ${ }^{1}$, JC Tardif ${ }^{2}$,

J Rodès-Cabeau ${ }^{1}$, E Larose ${ }^{1}$, OF Bertrand ${ }^{1}$

${ }^{1}$ Unité de recherche en pneumologie, Centre de recherche de

I'Hôpital Laval, Institut universitaire de cardiologie et de pneumologie, Université Laval, Québec; ${ }^{2}$ Institut de cardiologie de Montréal, Montréal, Québec

INTRODUCTION: Le syndrome d'apnée et d'hypopnée du sommeil (SAHS) est un facteur de risque important pour les maladies cardiovasculaires. Des études ont démontré son rôle dans la dysfonction endothéliale, l'hypertension artérielle, l'insuffisance cardiaque et la maladie coronarienne. Nous pensons que la présence et la sévérité du SAHS peuvent influencer les paramètres de la plaque athérosclérotique coronaire, mesurée par échographie intravasculaire tridimensionnelle.

MÉTHODE: Les sujets ont été identifiés à partir d'un groupe de 133 patients avec une maladie coronarienne stable. Ces sujets avaient participé à deux études de progression-régression de l'athérosclérose, où l'athérosclérose coronaire avait été mesurée par échographie intravasculaire. Dix-neuf patients ont rencontré les critères d'inclusion/exclusion et ont complété un enregistrement polysomnographique.

RÉSULTATS: Les sujets avaient un âge moyen de $61 \pm 8$ ans, un IMC moyen de 29,3 $\pm 4,8 \mathrm{~kg} / \mathrm{m}^{2}$ et un tour de taille moyen de $103 \pm 11 \mathrm{~cm}$. L'index d'apnée hypopnée (IAH $=$ nombre d'événements apnéiques et hypoapnéiques par heure de sommeil) était supérieur à 15 chez 11/19 patients $(58 \%)$. Les patients avec un $\mathrm{IAH} \geq 15$ avaient un volume de 
plaque plus important que les patients avec IAH $<15\left(243 \pm 70 \mathrm{~mm}^{3}\right.$ vs $\left.170 \pm 59 \mathrm{~mm}^{3}, \mathrm{p}=0,03\right)$. Il existait une relation positive significative entre le volume de la plaque athéromateuse coronaire et l'IAH $(r=0,6, p=0,01)$. CONCLUSION: Chez les patients avec une maladie coronarienne stable, le volume de la plaque athéromateuse coronarienne est plus important chez les patients avec un IAH $\geq 15$ comparativement aux patients avec un $\mathrm{IAH}<15$. De plus, il existe une relation entre l'importance de l'athérosclérose coronaire et la sévérité du SAHS. Nos résultats suggèrent que SAHS pourrait être un facteur de risque indépendant de l'athérosclérose coronaire.

\section{0}

\section{APPORTS CALORIQUES CHEZ LES ENFANTS SOUS ASSISTANCE RESPIRATOIRE EN SOINS INTENSIFS}

P louvet, B Bockenkamp, A Monir, A Proietti, VA Pelletier Pediatric department, Montreal University, Sainte-Justine Hospital, Montreal, Quebec

INTRODUCTION: Aux soins intensifs pédiatriques (USIP), l'apport nutritionnel est dépendant de l'estimation de ses besoins, de la prescription de la nutrition et de l'administration réelle de ce qui a été prescrit. Nous avons réalisé une étude descriptive afin d'évaluer chacune de ces étapes.

MÉTHODES: Du 1 Mai au 31 Août 2005, les enfants admis dans l'USIP de l'hôpital Sainte Justine, sous assistance respiratoire et séjournant 3 jours ou plus ont été inclus. Les données anthropométriques, l'apport calorique quotidien prescrit et reçu du $3^{\text {ème }}$ jour au $28^{\text {ème }}$ jour d'hospitalisation étaient relevés. Ces apports étaient comparés aux recommandations de l'American Society of Parenteral and Enteral Nutrition de 2002 (ASPEN), en vigueur dans l'USIP. Lorsqu'il existait un écart entre les calories prescrites et les calories reçues (delta cal), la raison de cet écart était notée.

RÉSULTATS: Quarante neuf des 298 patients admis en USIP ont été inclus. La durée médiane de ventilation était de 10 jours. Trente patients sur 49 étaient à risque de dénutrition selon la définition de Waterlow (BMJ 1972;3:566). Le nombre de patients ayant une prescription de calories assurant les apports recommandés par l'ASPEN au jour 3, 7, 14 et 21 était de 2/49, 12/40,6/20,5/10 respectivement. Un delta cal $\geq$ $10 \mathrm{Cal} / \mathrm{kg} /$ jour était observé dans $163 / 579$ des journées étudiées pour l'alimentation entérale $(28.1 \%)$ et $1 / 579$ pour l'alimentation parentérale (0.2\%). La principale cause de diminution de l'alimentation entérale était la réalisation d'une procédure (par exemple, $40.8 \pm 20.9 \mathrm{kcal} / \mathrm{kg} /$ jour pour une extubation).

CONCLUSIONS: Notre étude montre que malgré un risque de dénutrition à l'admission en USIP : 1) les apports caloriques prescrits sont basés sur des recommandations pour l'enfant sain, 2) les prescriptions ne suivent pas ces recommandations dans plus de $50 \%$ des cas, 3) dans plus d' $1 / 4$ des journées étudiées, les calories prescrites par voie entérale ne sont pas administrées, essentiellement du fait de procédures.

Financement : Direction des services professionnels - Hôpital Sainte Justine

\section{1}

\section{OBSTRUCTIVE SLEEP APNEA IN HIGH-RISK ABDOMINALLY OBESE DYSLIPIDEMIC MEN WITH FEATURES OF THE METABOLIC SYNDROME}

L Hins $^{1}$, P Poirier ${ }^{1}$, N Alméras ${ }^{1}$, A Tremblay ${ }^{1,2}$, J Bergeron ${ }^{3}$, JP Després ${ }^{1,2}$, $F$ Sériès ${ }^{1}$

${ }^{1}$ Institut universitaire de cardiologie et de pneumologie, Centre de Recherche de l'Hôpital Laval, ${ }^{2}$ Division de Kinésiologie, Université Laval, ${ }^{3}$ Centre de recherche sur les maladies lipidiques, CHUL, Québec

OBJECTIVE: To assess the relationship between characteristics of sleepinduced respiratory disturbances and different anthropometric variables as well as several metabolic risk factors for cardiovascular disease in men.

METHODS: One hundred two subjects with the metabolic syndrome were evaluated. Nocturnal home oximetry was used to determine the sleep apnea status. The following oximetric indices were included as independent variables in the statistical analyses: Respiratory disturbance index (RDI) and the percentage total recording time spent below a saturation of
90\% (\% TRT < $90 \% \mathrm{SaO}_{2}$ ). Independent measures included anthropometric variables [body mass index (BMI), waist (WC) and neck circumferences (NC)] and metabolic risk factors [blood pressure (BP), fasting lipoprotein-lipid, glucose, insulin and leptin levels].

RESULTS: In this population of men characterized by a BMI of $30.7 \pm 3.1 \mathrm{~kg} / \mathrm{m}^{2}$, average $\mathrm{WC}$ and $\mathrm{NC}$ of $107.6 \pm 8.6 \mathrm{~cm}$ and $42.5 \pm 2.5 \mathrm{~cm}$, respectively, mean RDI was $13.3 \pm 15.9$ whereas average \% TRT $<90 \% \mathrm{SaO}_{2}$ reached $4.0 \pm 11.4 \%$. Twenty-four percent of these subjects had a RDI $\geq 15 / \mathrm{h}$ with a $\%$ TRT $<90 \% \mathrm{SaO}_{2}$ of $13.1 \pm 20.5 \%$. Significant positive correlations were observed between RDI and BMI $(r=0.21, p<0.05)$, WC $(r=0.24, p<0.05), N C(r=0.30, p<0.01)$ and leptin levels $(r=0.24$, $\mathrm{p}<0.05)$. Significant relationships were obtained between the previous anthropometric variables with \% TRT $<90 \% \mathrm{SaO}_{2}$ [BMI $(\mathrm{r}=0.27, \mathrm{p}<0.01)$, WC $(r=0.27, p<0.01), \mathrm{NC}(\mathrm{r}=0.29, \mathrm{p}<0.01)]$.

CONCLUSION: Almost one-quarter of high-risk abdominally obese dyslipidemic men without known apnea were found to be characterized by nocturnal desaturations. Leptin was significantly correlated with the number of desaturation events.

\section{2}

\section{ASTHMA CONTROL AND AIRWAY OBSTRUCTION IN ASTHMATIC PATIENTS WITH OR WITHOUT POLYPOID RHINITIS}

L Bilodeau, ME Boulay, P Boisvert, LP Boulet

Hôpital Laval, Institut universitaire de cardiologie et de pneumologie, Québec

BACKGROUND: Nasal polyposis (NP) affects about $5 \%$ of asthmatic patients. These last seem to present with a more severe and steroid-resistant asthma.

PURPOSE: To compare asthma control and airway obstruction of asthmatic patients with (ANP) or without (A) nasal polyps using (+) or not (-) bronchial anti-inflammatory medication.

METHODS: Asthma control was assessed according to the Asthma Control Scoring System (Boulet et al. CHEST 2002) including a \% score for clinical (Clin), physiological (Phys) and inflammatory (Inflam) parameters. Expiratory flows, induced sputum eosinophils (ISE) and blood eosinophils (BE) were also measured.

RESULTS: ACSS (Global) score was lower in group ANP+ (significant difference only compared to group ANP- and group A-, p< 0.05) (Table 1). $\mathrm{FEV}_{1}$ and the ratio $\mathrm{FEV}_{1} / \mathrm{FVC}$ were lower in group $\mathrm{ANP}+(\mathrm{p}<0.05)$ (Table 1). Blood and sputum eosinophils were higher in group ANP+ $(\mathrm{p}<0.05)$ (Table 1).

\section{TABLE 1}

\begin{tabular}{lllll} 
Group & ANP+ & ANP- & A+ & A- \\
\hline $\mathrm{N}$ & 24 & 15 & 20 & 20 \\
ACSS (Global) (\%) & 67 & $84^{*}$ & 79 & $85^{*}$ \\
Clin (\%) & 86 & 92 & 88 & 93 \\
Phys (\%) & 73 & 86 & 84 & $95^{*}$ \\
Inflam (\%) & 43 & $75^{*}$ & $66^{*}$ & $68^{*}$ \\
$\% \mathrm{FEV}_{1}\left(\mathrm{FEV}_{1} / \mathrm{FVC}\right)$ & $74(66)$ & $93(76)^{*}$ & $89(73)^{*}$ & $104(78)^{*}$ \\
$\mathrm{BE}(\%)$ & 6.6 & $3.7^{*}$ & $4.0^{*}$ & $3.8^{*}$ \\
ISE (\%) & 16 & $2^{*}$ & $4^{*}$ & $4^{*}$ \\
\hline
\end{tabular}

${ }^{*} p<0.05$ vs ANP+. Results are presented as means.

CONCLUSION: Asthmatic subjects with nasal polyposis using antiinflammatory medication show increased airway obstruction, markers of inflammation and reduced asthma control compared to the other groups. 
63 EFFECT OF SALMETEROL/FLUTICASONE PROPIONATE
COMBINATION ON AIRWAY INFLAMMATION IN COPD
SUBJECTS COMPARED TO FLUTICASONE V Govindaraju ${ }^{1}$, P Christodoulopoulos ${ }^{1}$, F Maltais ${ }^{3}$, Y Yamauchi ${ }^{2}$, R Olivenstein ${ }^{1}$, Q Hamid ${ }^{2}$, J Bourbeau ${ }^{1}$

${ }^{1}$ Respiratory Epidemiology and Clinical Research Unit, Montreal Chest Institute, McGill University Health Centre; ${ }^{2}$ Meakins-Christie Laboratories, McGill University, Montréal; ${ }^{3}$ Centre de recherche, Hôpital Laval, Institut Universitaire de cardiologie et de pneumologie, Université Laval, Québec

Airway inflammation in chronic obstructive pulmonary disease (COPD) is characterized by infiltration of CD8+ and CD68+ cells, and an increased number of neutrophils, whereas few studies have described the presence of eosinophils. Although the anti-inflammatory effects of corticosteroids in stable COPD are unclear, recent studies suggest that patients could benefit from combination therapy. We evaluated combined salmeterol/fluticasone propionate (SFC) and fluticasone propionate (FP) alone, on inflammatory cells in the airways of COPD patients. Patients were treated in a randomized, double-blind, parallel-group, placebo-controlled trial with either a combination of $50 \mu \mathrm{g}$ salmeterol and $500 \mu \mathrm{g}$ FP twice daily ( $\mathrm{n}=19,19$ male, mean age 62), $500 \mu \mathrm{gP}$ twice daily ( $\mathrm{n}=20,15$ male, mean age 64$)$, or placebo ( $n=21,17$ male, mean age 66$)$ for 3 months. At the start and end of treatment, bronchoscopy with bronchial biopsies was performed, and numbers of CD8+ T-lymphocytes, CD68+ macrophages, neutrophils and eosinophils were measured. CD8 + cells were significantly reduced by SFC compared with P $\left(-98.05\right.$ cells $\left./ \mathrm{mm}^{2} ; \mathrm{p}<0.001\right)$ and with FP $\left(-53.37\right.$ cells $\left./ \mathrm{mm}^{2} ; \mathrm{p}<0.05\right)$. Such a marked effect was not seen with FP alone $\left(-44.67 \mathrm{cells} / \mathrm{mm}^{2} ; \mathrm{p}=0.06\right)$. CD68+ macrophages were also reduced by the SFC compared with P $\left(-31.68\right.$ cells $/ \mathrm{mm}^{2}$; $\left.\mathrm{p}<0.05\right)$ but not by FP. Number of neutrophils on the other hand were not reduced in response to SFC, but were significantly lower when compared to FP $\left(-22.785\right.$ cells $\left./ \mathrm{mm}^{2} ; \mathrm{p}<0.05\right)$. There were no changes in eosinophils. Our results suggest that combination therapy has airway anti-inflammatory effects not seen with inhaled corticosteroids alone.

Research project funded by GlaxoSmithKline
64

\section{LA VARIABILITÉ DES DÉBITS DE POINTE DURANT LES PÉRIODES AU ET HORS TRAVAIL DIFFÈRE-T-ELLE ENTRE LES SUJETS AVEC ASTHME PROFESSIONNEL ET ASTHME EXACERBÉ AU TRAVAIL?}

S Chiry, A Cartier, C Lemière

Pneumologie-recherche, Hôpital de Sacré-Cœur de Montréal,

Montreal, Québec

INTRODUCTION: L'Asthme professionnel (AP) est causé par des agents spécifiques retrouvés dans le milieu de travail, tandis que l'asthme exacerbé par le travail (AET) est aggravé par les conditions professionnelles sans être causé par un agent spécifique. Le degré de variabilité des débits de pointe (DEP) durant les périodes au et hors travail n'a pas été évalué chez les sujets atteints d'AET.

BUT: Comparer la variabilité quotidienne des DEP durant des périodes au et hors travail chez des sujets atteints d'AP et d'AET.

MÉTHODES: Les sujets référés dans notre centre pour possibilité d'AP ont mesuré de façon sériée leur DEP pendant deux périodes de deux semaines au et hors travail. Par la suite, des tests de provocation spécifique ont été réalisés. Les sujets avec un test positif ont été définis comme ayant un AP, ceux avec un test négatif comme ayant un AET. La variabilité quotidienne des DEP a été calculée au travail et hors travail. Les DEP ont été reproduits sur des graphiques dont l'analyse visuelle a été faite par 5 experts.

RÉSULTATS: Quarante sujets ont été recrutés, 21 avec AP et 19 avec AET. La variabilité quotidienne des DEP était accrue durant les périodes au travail comparée aux périodes hors travail chez les sujets avec AP $(19,7 \pm 8,6 \%$ vs $11,2 \pm 6,4 \% \mathrm{p}<0,001)$ et avec AET $(13,5 \pm 4.9 \%$ vs $9,4 \pm 6,0 \% \mathrm{p}=0,005)$. Cependant, la variabilité du DEP observée entre les périodes au et hors travail était plus marquée chez les sujets avec AP $(+8,4 \pm 7,3 \%)$ qu'avec AET $(+4,0 \pm 5,4 \% \mathrm{p}=0,04)$. Il existait une importante discordance entre les experts dans l'interprétation visuelle des DEP $(\mathrm{k}=0,23)$. CONCLUSIONS: L'exposition professionnelle induit une variabilité accrue des DEP chez les sujets avec AP et AET mais celle-ci est plus prononcée dans l'AP. L'analyse visuelle des DEP ne permet pas de distinguer de façon fiable AP et AET.

\section{Author Index / Liste des auteurs (by abstract number)}

\section{A}

Alméras N . . . . ..............61

Amraei $\mathrm{MG} \ldots \ldots \ldots \ldots \ldots \ldots$

Amyot R ....................53

B

Bacon SL . . . . . . . . . . . . . . . . . . 18,34,56 . . . .

Baillot R . . . . . . . . . . . . . . . . . . . . . . . .

Bairam A $\ldots \ldots \ldots \ldots \ldots \ldots \ldots$

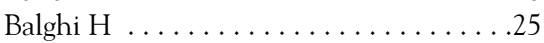

Baltzan MA . . . . . . . . . . . . . . . . . . . . . . . . .

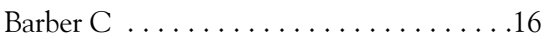

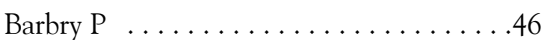

Barriga $P \ldots \ldots \ldots \ldots \ldots \ldots$

Beauchamp G . . . .............. 30

Beaulieu MJ . . ..............15

Beaulieu-Genest L . . . . . . . . . . . . . 17

Bellemare F . . . . . . . . . . . . . 9,24

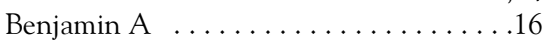

Bergeron J . . . . . . . . . . . . . 61

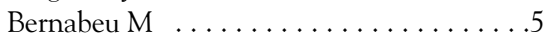

Bernard $S \ldots \ldots \ldots \ldots \ldots \ldots \ldots \ldots$

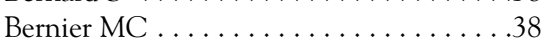

Berthiaume $Y \ldots \ldots \ldots \ldots \ldots \ldots . \ldots 46$

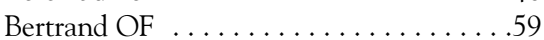

Biardel S . . . . . . . . . . . . . . 41

Bilodeau L . . . . . . . . . . . . . . . . 62
Bissonnette E . . . . . . . . . . . . 44,45

Bockenkamp B ..............60

Boisvert P . . . . . . . . . . . . . .62

Bonloke J . . . . . . . . . . . . . 15

Borduas F ................... 36

Borel JC . . . . . . . . . . . . . . . . . . . . . . .

Bouchard A . . . . . . . . . . 18,34,56

Bouchard N . . . . . . . . . . . . . . . 51

Boucher E ....................... 39

Boulay ME . . . . . . . . . . . . 33,62

Boulet LP . . . . . . . . . 33,41,44,52,59,62

Bourbeau J . . . . . . . . . . . . . . . . . . . . . . . . . . . . . . .

Bourret JC . . . . . . . . . . . . . 48

Bouyer L . . . . . . . . . . . . . . . . . . 57

Breton MJ . . . . . . . . . . . . . . . . . . . . . . . . . 58

Brochiero E . . . . . . . . . . . . . 1,46,48

Brochu C . . . . . . . . . . . . . . . . . . . . . . . . . . .

Brodeur J . . . . . . . . . . . . . . . . . 50

Brouillard C . . . . . . . . . . . . 19,57

\section{C}

Caron $\mathrm{M} \ldots \ldots \ldots \ldots \ldots \ldots \ldots . \ldots \ldots$

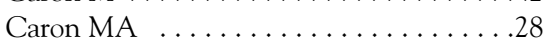

Cartier A . . . . . . . . . . . . . . . 53,56,64

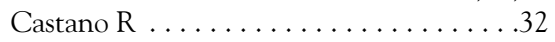

Cesarini C . . . . . . . . . . . . . . 30

Chagnon K ..................53
Chakir J . . . . . . . . . . . 7,35,38,41

Chamberland A ............... 38

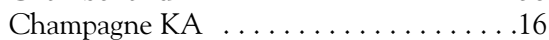

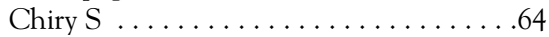

Chouinard F . . . . . . . . . . . . 4

Chrétien D ................... 17

Christodoulopoulos P . . . . . . . . . 63

Chupin C . . ...............46

Cormier Y . . . . . . . . . . . . . . 15

Croteau $S \ldots \ldots \ldots \ldots \ldots \ldots \ldots \ldots \ldots 11$

\section{D}

Daigle $S \ldots \ldots \ldots \ldots \ldots \ldots . \ldots 27$

Daley D . . . . . . . . . . . . . . 42

Danialou G . . . . . . . . . . . . . 25

Debigaré R ............. 2,28,57

Delage A . . . . . . . . . . . . . . . . 99

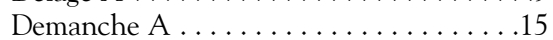

Deschênes D . . . . . . . . . . . . . . 20

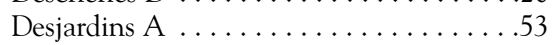

Després JP . . . . . . . . . . . . . 61

Dionne B ................... 52

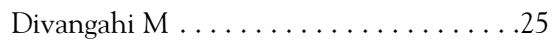

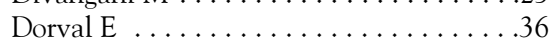

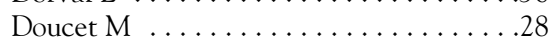

Dubé J . . . . . . . . . . . . . . . 35

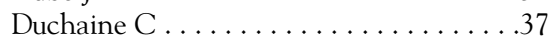

Dupuis $G \ldots \ldots \ldots \ldots \ldots \ldots$ 


\section{$\mathbf{E}$}

Échavé V . . . . . . . . . . . . . . . . . . . 40

Ernst P ...................54

F

Favreau H . . . . . . . . . . 14,18,34

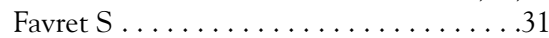

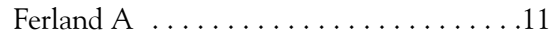

Ferland C . . . ................26

Foley JS . . . . . . . . . . . . . . 27

Forest $\mathrm{V} \ldots \ldots \ldots \ldots \ldots \ldots \ldots \ldots$

Forster RJ . . . . . . . . . . . . . . 37

\section{G}

Gadoury MA . . . . . . . . . . . . . . .58

Garcia-Asensi A ................21

Gautrin D . . . . . . . . . . . . . . 32

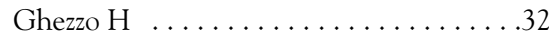

Godin N . . . . . . . . . . . . . . . . 3

Gomes MM . . . . . . . . . . . . . . 40

Goulet S . . . . . . . . . . . . . 36

Govindaraju V . . . . . . . . . . .63

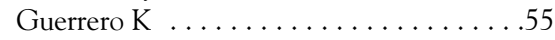

Gvozdic D . . . . . . . . . . . . . 25

H

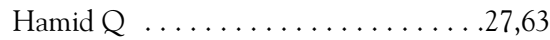

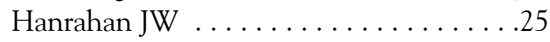

Hassan M . . . . . . . . . . . . . . . . . .43

Hins J ...................61

Hudson TJ . . . . . . . . . . . . . . 442

I

Israel-Assayag E . . . . . . . . . . 15

$\mathbf{J}$

Jacques $E \ldots \ldots \ldots \ldots \ldots \ldots \ldots \ldots \ldots 41$

Jo T ................ . . 43

Joanisse DR . . . . . . . . . . . . . . 28

Jobin V . . . . . . . . . . . . . . . . . . 9, 9,24

Joseph $V \ldots \ldots \ldots \ldots \ldots \ldots \ldots . \ldots . \ldots 23$

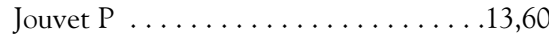

Julien $\mathrm{M} \ldots \ldots \ldots \ldots \ldots \ldots \ldots \ldots 14$

\section{$\mathbf{K}$}

Kassissia I . . . . . . . . . . . . . . . . .21

Kheir $L \ldots \ldots \ldots \ldots \ldots \ldots \ldots \ldots \ldots$

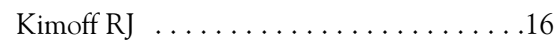

Kinkead R . . . . . . . . . . . . . .8

\section{$\mathbf{L}$}

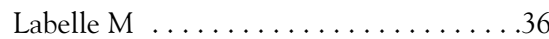

Laberge F . . . . . . . . . . . . . . . . .51

Labidi $M \ldots \ldots \ldots \ldots \ldots \ldots \ldots \ldots \ldots$

Labrecque $M \ldots \ldots \ldots \ldots \ldots \ldots$. . . . . . . . . . . . .

Labreque M . . . . . . . . . . . . . . . . . 34

Lacasse Y . . . . . . . . . . . . . . . . . . . . .

Lacroix J . . . . . . . . . . . . . . 13

Lafond C . . . . . . . . . . . . . . . 22

Langlois A . . . . . . . . . . . . . . 4,26

Langsetmo L . . . . . . . . . . . . . . .54

Laprise C . . . . . . . . . . . . . . 38,42,45

L'Archeveque L . . . . . . . . . . . . . . . 27

Larose E . . . . . . . . . . . . . . . . . . . . . . . . . . . . . 59

Laurin C . . . . . . . . . . . . . . . .56

Laviolette L . . . . . . . . . . . . . . 57,58

Laviolette M . . . . . . . . . . . 4,26,38,41,45

Lavoie JP . . . . . . . . . . . . . . . . . . . . .30

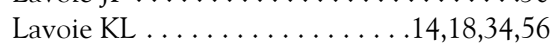

Lavoie-Lamoureux A . . . . . . . . . . . 30

LeBlanc P . . . . . . . . . . . . . . . . . . 20,28,50 . . . . . .

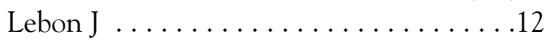

Lefter R ...................23

Léger $B \ldots \ldots \ldots \ldots \ldots \ldots \ldots \ldots$

Lemière $\mathrm{C} \ldots \ldots \ldots \ldots \ldots \ldots \ldots$. . . . . . . . . . . . . . . . . . . . .

Lemire $M \ldots \ldots \ldots \ldots \ldots \ldots 42$

Leroy $\mathrm{C} \ldots \ldots \ldots \ldots \ldots \ldots \ldots \ldots \ldots$

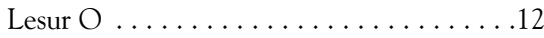

Létourneau V . . . . . . . . . . . . . . . 37

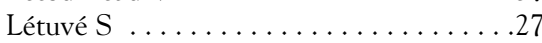

Levy P . . . . . . . . . . . . . . . . 55

Loubaki L . . . . . . . . . . . . . . . .7

\section{M}

Maclet E ...................55

Madore AM ...................45

Maghni K . . . . . . . . . . . . . . . . . . . 6,31 . . . . . .

Mallozzi A . . . . . . . . . . . . . . . . 16

Malo JL . . . . . . . . . . . . . . . 27,32

Maltais F . . . . 2,17, 19,20,28,50,52,57,58,63

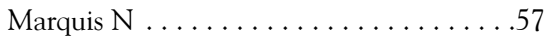

Martin J . . . . . . . . . . . . . . . . .11

Martin JG . . . . . . . . . . . . . . 5,30,43

Martin S . . . . . . . . . . . . . . . 51

Mathieu A .................47

Mayer P . . . . . . . . . . . . . . . . . . 9,24

McGovern T . . . . . . . . . . . . . 43

Mériaux A . . . . . . . . . . . . . . . . 37

Mezin P . . . . . . . . . . . . . . . . . .55

Micheau P . . . . . . . . . . . . . . . . .12

Milot J . . . . . . . . . . . . . . . . . . . . . . . . 29, . . . 131,50

Monir A . . . . . . . . . . . . . . . 13,60

Montandon $G \ldots \ldots \ldots \ldots \ldots \ldots . \ldots . \ldots$

Montpetit A . . . . . . . . . . . . . . 42

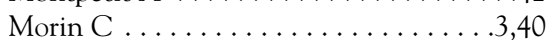

Morin L . . . . . . . . . . . . . . . . . . . 16

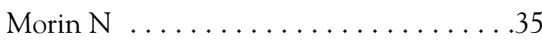

Morin $\mathrm{T} \ldots \ldots \ldots \ldots \ldots \ldots \ldots \ldots . \ldots \ldots 22$

Morissette M . . . . . . . . . . . . . . 29

Naor $\mathrm{N} \ldots \ldots \ldots \ldots \ldots \ldots \ldots \ldots \ldots$

Nehmé B . . . . . . . . . . . . . . . . 37

Noël J . . . . . . . . . . . . . . 1

\section{$\mathbf{O}$}

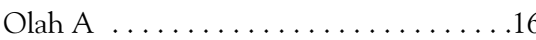

Olivenstein R ..............63

Opatrny L . . . . . . . . . . . . . . 16

\section{$\mathbf{P}$}

Page D ......................11

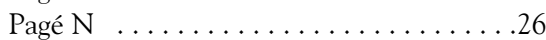

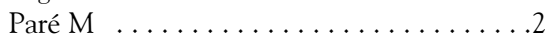

Paré PD ...................42

Paren J .........................29

Parent JG . . . . . . . . . . . . . . . 17

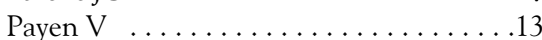

Pelland F . . . . . . . . . . . . . . . . .22

Pelletier VA . . . . . . . . . . . . . . 60

Pepin V . . . . . . . . . . . . . . . . . 19,20,50 . . . .

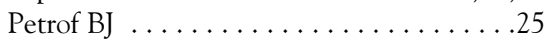

Piccioni M . . . . . . . . . . . . . 18,34

Pison C . . . . . . . . . . . . . . . . . . .55

Plante S . . . . . . . . . . . . . . . 35,41

Platt R . . . . . . . . . . . . . . . . . . .54

Poirier $\mathrm{C} \ldots \ldots \ldots \ldots \ldots \ldots \ldots \ldots$

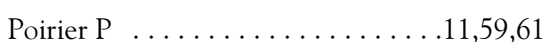

Praud JP . . . . . . . . . . . . . . . 12

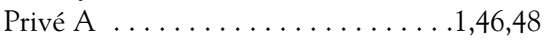

Proietti A .................60

$\mathbf{R}$

Raby B ..................51

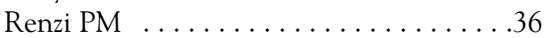

Revill S . . . . . . . . . . . . . . . . .19

Richard K . . . . . . . . . . . . . . .47

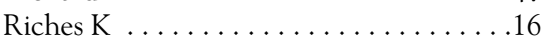

Robert R . . . . . . . . . . . 12,25

Rodès-Cabeau J . . . . . . . . . . . . . . . . . . . .59

Rondeau G . . . . . . . . . . . . . . . . . . 24

Rouleau M . . . . . . . . . . . . . 36,58

Roumiana G . . . . . . . . . . . . . . . . . 47

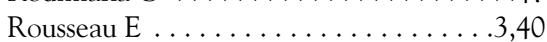

Rousseau MC ..................33

Russell AP . . . . . . . . . . . . . . . . . . . 28

$\mathbf{S}$

Saey D . . . . . . . . . . . . . . . 20,57

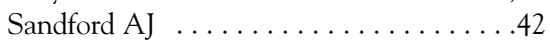

Santschi M ..................13

Schwartzman K . . . . . . . . . . . . . . 16

Sébastien F . . . . . . . . . . . . . . . . 47

Semlali A ................41

Sériès F . . . . . . . . . . . . 7,10,11,59,61

Shalaby K . . . . . . . . . . . . . . . . . . . . . . . . . .

Siddiqui $S \ldots \ldots \ldots \ldots \ldots \ldots \ldots$

Similowski T . . . . . . . . . . . . . . . . . 10

Singh S . . . . . . . . . . . . . . . . . . 19

Sirois $M \ldots \ldots \ldots \ldots \ldots . \ldots 40$

St-Jacques B .................. 31

St-Laurent J . . . . . . . . . . . . . . . . 44

Sully J . . . . . . . . . . . . . 21

Sumi Y ....................27

\section{$\mathbf{T}$}

Tamaoka M ..................43

Tanzimat G . . . . . . . . . . . . 21

Tardif JC . . . . . . . . . . . . . . . . . .59

Tétreault PG $\ldots \ldots \ldots \ldots \ldots \ldots \ldots \ldots \ldots$

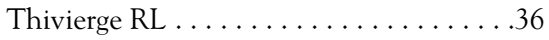

Tremblay A . . . . . . . . . . . . . . .61

Tremblay K . . . . . . . . . . . . . . . . . . 38,42

Tremblay Y . . . . . . . . . . . . . . . . 39

Trinh NTN . . . . . . . . . . . . . . . 1

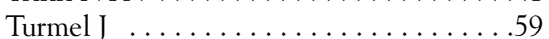

Turmel V . . . . ............45

\section{V}

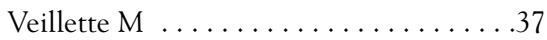

Verreault $\mathrm{C} \ldots \ldots \ldots \ldots \ldots \ldots \ldots \ldots$

Vivodtzev I . . . . . . . . . . . . . . . 55

W

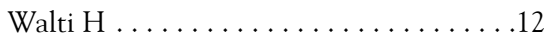

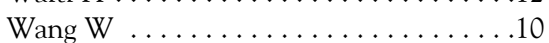

Welman M ................6,31

Whittom F . . . . . . . . . . . . . . . 50

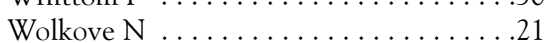

Wuyam B .................55

$\mathbf{Y}$

Yamauchi $Y \ldots \ldots \ldots \ldots \ldots \ldots \ldots 63$ 


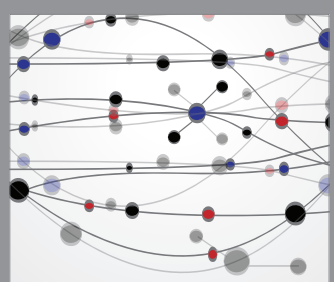

The Scientific World Journal
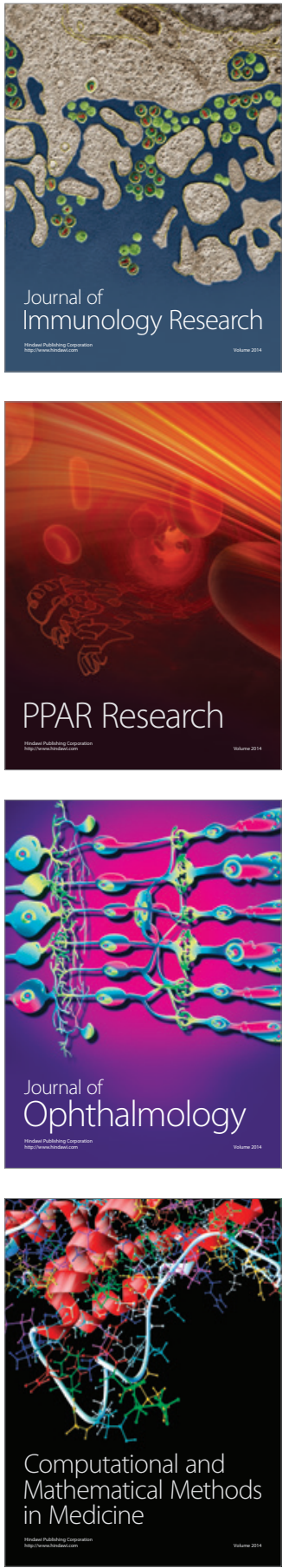

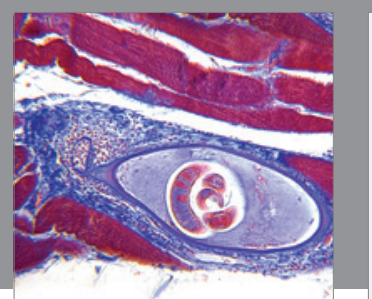

Gastroenterology Research and Practice

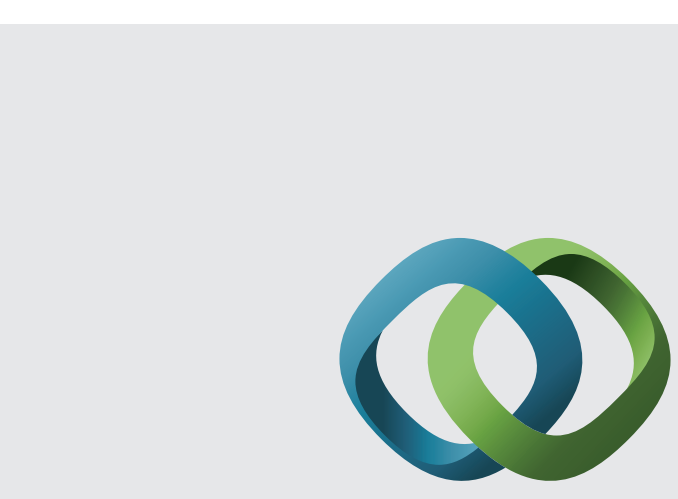

\section{Hindawi}

Submit your manuscripts at

http://www.hindawi.com
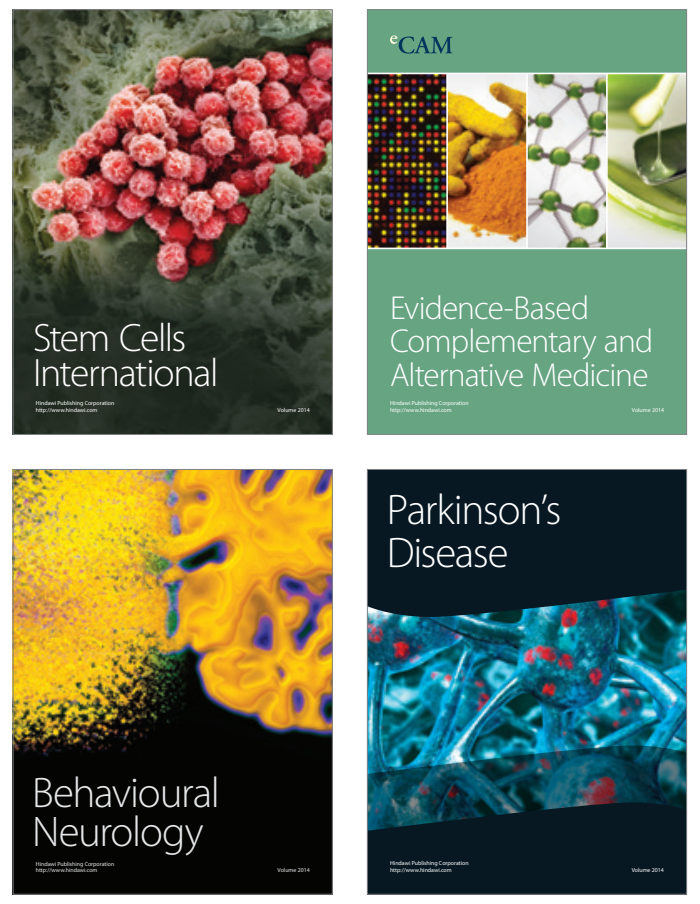
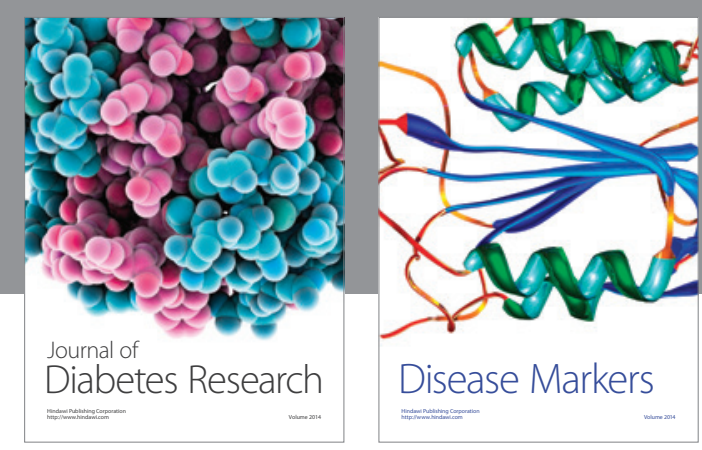

Disease Markers
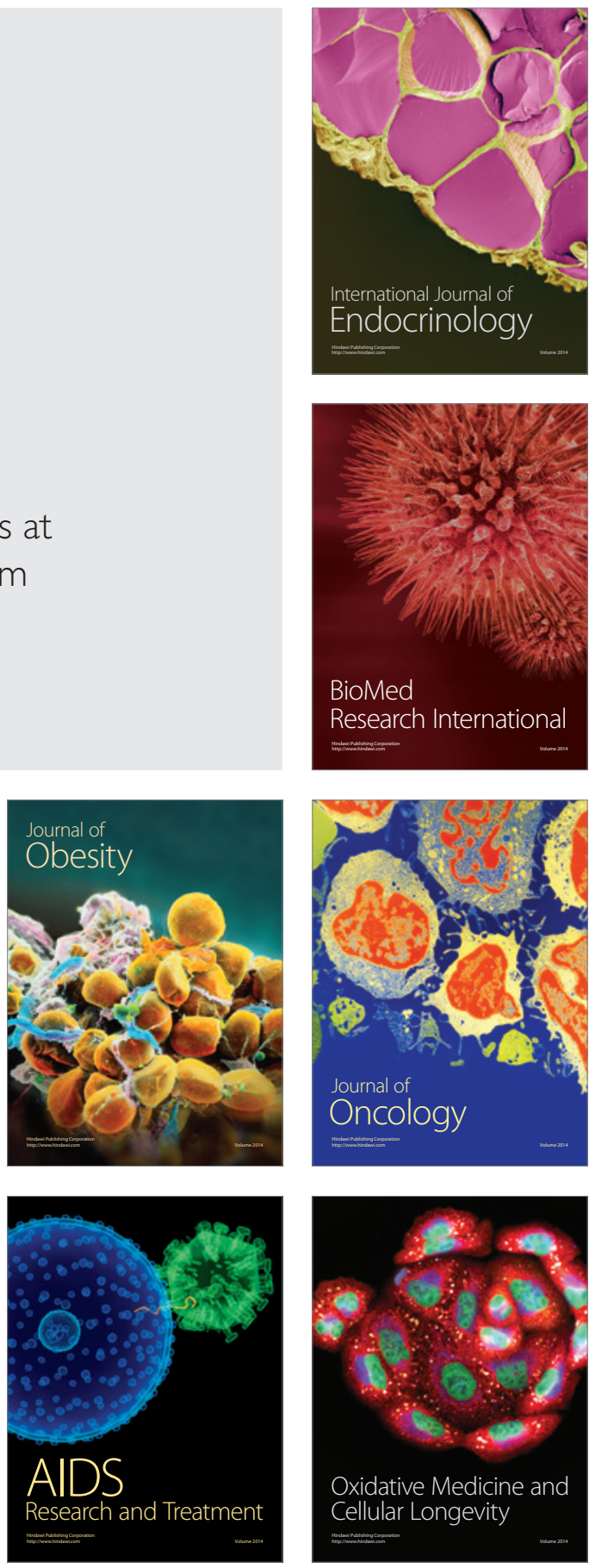